\title{
What determines the location of equity trading? \\ Evidence from stocks cross-listed in various markets
}

\author{
Olga Dodd* \\ Auckland University of Technology, Auckland, New Zealand \\ Krishna N. Paudyal \\ University of Strathclyde, Glasgow, United Kingdom
}

\begin{abstract}
We analyse the distribution of foreign trading volume of European stocks cross-listed on various stock exchanges and examine the factors that affect the distribution. We focus on the role of two sets of determinants: the stock exchange characteristics and the stock-specific factors. We find that a stock exchange's ability to attract order flow of foreign equity is positively associated with its organizational efficiency, market liquidity, the regulations pertinent to the quality of investor protection and insider trading. Regulated stock exchanges are found to be more successful in attracting order flow of foreign stocks than non-regulated markets, such as OTC and alternative markets and trading platforms. Among the stock-level factors, the share of trading on a foreign exchange is higher for companies that are smaller, riskier and have low return correlation with the host market returns. It is also evident that the share of foreign trading volume of stock is higher when the currencies of host and home markets are the same and the share increases with the duration of a listing.
\end{abstract}

Keywords: stock exchange, equity trading, cross-listing

JEL classification: G15, G12

EFM classification: 330,360

\footnotetext{
$\bar{a}$ corresponding author. Email: olga.dodd@aut.ac.nz. Address: Department of Finance, Faculty of Business and Law, Auckland University of Technology, Private Bag 92006, Auckland 1142, New Zealand
} 


\section{INTRODUCTION}

Technological advances of the last decade have resulted in significantly intensified competition within the stock exchange industry. In response, stock exchanges have gone through dramatic changes. ${ }^{1}$ In the new business environment, a stock exchange's competiveness is a function of the exchange's ability to 'attract order flow and so provide liquidity to investors' (Aggarwal, 2002). ${ }^{2}$ Therefore, we analyse the factors that determine the ability of stock exchanges in pulling order flows of foreign stocks. We also examine the role of stock specific factors in the distribution of their trading volume in foreign exchanges, which is important because some provisions of stock exchanges may be suitable for some firms but not for others. ${ }^{3}$

In theory, when a stock is listed on multiple markets, traders make decisions on the location of trading based largely on transaction costs (Pagano, 1989; Chowdhry and Nanda, 1991). Accordingly, it is expected that order flow from liquidity traders who seek to attain the highest possible level of liquidity will eventually gravitate to a single market with the lowest possible transaction costs. The theoretical models predict the equilibrium distribution of trading volumes for stocks that are traded on more than one market. As Pagano (1989) correctly observes that the conditions for the co-existence of two markets are unrealistic. Therefore, the likely scenario is that only one market with the most favourable transaction costs will survive. Similarly, Chowdhry and Nanda (1991) predict a 'winner takes most' equilibrium, meaning that traders concentrate on the most liquid market. Another important consideration for traders is the quality of the market's information environment. Huddart et al (1999) developed a theoretical model where liquidity traders choose to trade only on the exchange with the strictest disclosure requirements because on such exchanges the information advantage of corporate insiders is less.

\footnotetext{
${ }^{1}$ The changes in the stock exchange industry have included the demutualization of stock exchanges and stock exchanges becoming for-profit entities. This has been accompanied by stock exchange consolidations, the development of new market segments and alternative markets and the introduction of new trading systems and platforms.

Some evidence from the financial press on the intensified competition and the changes in stock exchange industry include: "In New York: Big Board faces growing threats from its rivals", The Asian Wall Street Journal (January, 20, 2000); "Stock market shakeout: A wave of stock market mergers heralds a new era of competition", National Post (July, 20, 2000); "Exchanges face up to competition”, Financial News (February, 22, 2004).

${ }^{2}$ Anecdotal evidence on the importance of trading volumes for the stock exchanges survival includes: "Lack of volume brings end to financial chapter", The Boston Globe, (October, 3, 2007).

${ }^{3}$ For example the effect of cost of listing, annual fees, and disclosure requirements could depend on firm size.
} 
Theoretical models predict that equity trading would agglomerate on a single market with the most favourable trading environment. However, validating those predictions after accounting for significant market frictions that potentially distort the predicted equilibrium is a challenging empirical task. Earlier studies show that the quality of the equity listing and trading environment is positively associated with the demutualized status of the exchange (Hughes and Zargar, 2006; Krishnamurti et al, 2003), the implementation of electronic trading (Jain, 2005), and the introduction and enforcement of insider trading regulation (Fisher, 1992; Bhattacharya and Daouk, 2002; Beny, 2005). In the integrated financial markets the competitive position of a stock exchange can be further strengthened by focusing on attracting business from abroad and several studies have examined the ability of a stock exchange to attract foreign listings (Pagano et al, 2001; Fernandes and Giannetti, 2009). There is no evidence, however, on the comparative ability of stock exchanges to attract trading volumes of foreign stocks.

Cross-listed stocks are traded on two or more markets that generally differ in their characteristics. Thus trading of cross-listed stocks provides a natural setting for empirical testing of theoretical models of multimarket trading. Empirical research on the distribution of trading volumes of cross-listed stocks trading (Pulatkonak and Sofianos, 1999; Baruch et al, 2007; Halling et al, 2008) indicates a great variability in the foreign market share of global trading and its determinants. Pulatkonak and Sofianos (1999) examine the distribution of trading activity of 254 NYSE-listed non-US stocks and its determinants including time-zone distance, whether the firm comes from developed or emerging economy, home-market commission rates and several other issue-specific factors. They report that altogether these factors explain $64 \%$ of the variation, but it is the time zone factor that is the most dominant: companies with home markets that trade around the same time-zone as the US are likely to be more active on the US markets. Baruch et al (2007) highlight the importance of correlation of stock's returns with that of the other assets traded on the market in explaining the distribution of order flow. They analyse the distribution of trading volumes of 251 non-US stocks cross-listed in the US and report that the US information factor, a proxy for the informativeness of the US market in explaining returns of the cross-listed stock, is the main determinant of the distribution of trading volumes between home and US markets. Halling et al (2008) use a sample of 437 non-US companies that are listed in the US and report that the portion of the US trade is higher for smaller, export oriented, high-tech companies, and for companies from home markets that have higher trading costs and weaker insider trading protection. 
Moreover, they report that foreign trading volumes peak right after the cross-listing date and then decrease dramatically in the subsequent six months.

While the existing empirical literature offers an excellent foundation for an analysis of multimarket trading volume their findings cannot be generalised as their sole focus has been on the distribution of trading volumes between the US market and the stock's home market based on samples of non-US stocks cross-listed in the US. Evidence from non-US markets is nevertheless importance as these markets differ significantly from the US stock exchanges in their institutional characteristics. Also, companies, particularly European companies, have a long tradition of listing on multiple exchanges. ${ }^{4}$ Therefore, analysis of the US as the single foreign host market does not allow the comparison of various host markets and does not provide any evidence on relative host market characteristics the determine the distribution of equity trading. In contrast to the existing research, we evaluate trading volume distribution of cross-listed stocks among multiple foreign stock exchanges and trading venues.

While the US exchanges attract foreign companies due to a large investor base and a high level of liquidity, other major non-US stock exchanges are also important as listing and trading locations of foreign stocks. According to the World Federation of Exchanges' statistics, in 2007 listed foreign companies constituted $18 \%$ of total number of listed companies on the NYSE, $10 \%$ on NASDAQ, $22 \%$ on LSE, $12 \%$ on Deutsche Borse, $19 \%$ on Euronext and $25 \%$ on SWX. In addition to the significant number of foreign companies listed, foreign equity trading contributes significantly to the exchanges' turnover: in 2007 the fraction of foreign equity trading in the total equity trading was $9 \%$ on the NYSE, $10 \%$ on NASDAQ, $41 \%$ on LSE, $8 \%$ on Deutsche Borse, $1 \%$ on Euronext, and $9 \%$ on SWX. The fraction of foreign equity trading differs among the exchanges and this can potentially be explained by variation in the stock exchange characteristics, such as market size, aggregate market liquidity, organizational structure, and market design.

Our sample consists of the 795 cross-listed stocks from 25 European countries, including 7 emerging markets. It includes all foreign listing and trading accounts of cross-listed stocks (subject to data availability). In total that gives 2,853 foreign trading accounts on more than 30 foreign stock exchanges (including OTC and trading platforms) between January 1990 and December 2007.

\footnotetext{
${ }^{4}$ For example, Volkswagen AG simultaneously listed its shares on 13 stock exchanges, Bayer AG listed on 10 exchanges, Deutsche Bank AG listed on 10 exchanges, Daimler Chrysler AG listed on 7 exchanges (Abee and Zimmermann, 2006).
} 
First, we examine characteristics of host stock exchanges that affect trading of foreign stocks. Exchange characteristics are the gravitational forces or the 'pull' factors of foreign equity trading. We measure a stock exchange's ability to attract foreign equity trading by the share of the stock's total trading volume taking place on the foreign stock exchange. We argue that a tradingvolume-based measure is appropriate as the main source of a stock exchange's revenues comes from trading commissions (Aggarwal, 2002). ${ }^{5}$ In turn, trading commissions are a function of trading volume. Thus, for a stock exchange's survival, it is crucial to succeed in attracting order flow, including order flow of foreign equity. We find that a stock exchange's ability to attract order flow of foreign equity is positively associated with a stock exchange's organizational efficiency, market liquidity, and the also the quality of investor protection and insider trading regulations.

We also evaluate the relative attractiveness of regulated markets vs. non-regulated markets (off-exchange venues such as OTC markets and trading platforms) that differ mainly in terms of additional disclosure and listing requirements. Off-exchange equity trading activity is largely ignored by academic research. Nevertheless, industry statistics show that as much as one third of cash equity trading of European blue chip stocks takes place over-the-counter. ${ }^{6}$ Also, Voth (2004) argues that OTC trading in equities is the main source of competition for stock exchanges. We find strong evidence that regulated stock exchanges are more successful in attracting order flow of foreign stocks than non-regulated markets.

Second, we examine stock-level characteristics, including listing characteristics, company characteristics and home country characteristics, that affect trading of foreign stocks for a pooled sample of observations from various host exchanges and also individually for major stock exchanges. Pagano et al (2002) show that the US exchanges are more successful in attracting listings of high-growth companies, technology companies and companies with a large share of foreign sales, whereas European exchanges mostly attract listings of companies with a strong

\footnotetext{
${ }^{5}$ This is because other sources of revenue have lost their significance: listing fees have been reduced because of intensified competition among exchanges, membership fees have been cancelled because of the demutualization processes, revenues from sales of market data have diminished because of technological advances which dramatically reduced the costs of obtaining such data.

Statistics on the sources of revenue of stock exchanges support the argument on the importance of trading commissions: according to the World Federation of Exchanges' 'Cost \& Revenue Survey 2006' listing fees is only a small fraction - on average less than $10 \%$ of total revenues of a stock exchange while trading commissions is the major revenue source - on average $50 \%$ of the total revenues.

6 "Exchanging Over the Counter". The Banker (2004), p.49.
} 
record of past profitability. ${ }^{7}$ Accordingly, we expect the determinants of the distribution of foreign trading to vary across host stock exchanges. We find that the proportion of trading on a foreign exchange is higher for smaller and riskier companies, and for companies that exhibit lower correlation of returns with market index returns in the host market. Also this proportion is higher when foreign trading takes place in the same currency as trading in the firm's home market and increases with the duration of a listing. Export-oriented foreign companies have better liquidity in the US. Stocks from emerging markets and from English-speaking countries have most active foreign trading in London, while larger companies from counties with stronger investor protection and a better information environment have a higher foreign trading volume share on VIRTX.

\section{HYPOTHESES DEVELOPMENT}

Arguably, two main forces affect the direction of the order flow of a foreign equity stock. On the one hand, there is a set of characteristics of a host exchange/market where trading of the stock takes place. On the other hand, there is a set of factors inherent to the traded stock and to the country of its origin. Stock-specific factors drive trading volumes towards the foreign market depending on the suitability of a particular host market for the stock. Therefore, the two major sets of determinants are: (a) pull factors i.e. host market characteristics and (b) stock-level factors.

\subsection{Pull factors of foreign equity trading}

Potentially, host market characteristics determine how favourable a foreign trading environment is and, consequently, determine the ability of the host exchange to pull foreign equity trading. The ability to attract foreign equity trading should be affected by both the host exchange characteristics and the host country characteristics.

\section{Host exchange characteristics}

Cross-listed stocks can be traded on both regulated markets, which are stock exchanges where the stock is listed subject to compliance with listing requirements, and on non-regulated markets, or trading venues where the stock is traded without meeting any disclosure or listings requirements. ${ }^{8}$ Since the higher level of disclosure of regulated markets reduces traders'

\footnotetext{
${ }^{7}$ In addition, there is industry evidence to suggest that exchanges specialize in stocks with particular characteristics. For example, companies traded on the NASDAQ stock exchange differ from those traded on NYSE, most prominently by company size and industry affiliation.

${ }^{8}$ In addition to over-the-counter (OTC) markets, in recent years a number of alternative markets and trading platforms have emerged that are similar to OTC markets in their admission rules, for example, the open
} 
information costs regulated markets are expected to outperform non-regulated markets in terms of attracting order flow of foreign stocks.

One of the main developments in the stock exchange industry since the early 1990s has been the trend to demutualize exchanges from not-for-profit member-owned organizations into publicly owned corporations, mainly as a response to technological advances and the increase in global competition (Aggarwal, 2002). Demutualized exchanges are arguably superior to mutualised exchanges due to a more flexible governance structure, greater investor participation and greater access to global markets and capital (Hughes and Zargar, 2006). Empirical evidence suggests that demutualized stock exchanges provide a better quality market (Krishnamurti et al, 2003) and demonstrate a higher level of technical efficiency (Serifsoy, 2008). Thus, demutualized exchanges are expected to have superior ability to attract foreign equity trading compared to that of mutualised exchanges.

The other prominent innovation in the stock exchange industry in the last 20 years has been the dramatic change in market design due to technological advances, specifically, the introduction of automated or electronic trading as an addition to and later a replacement for, traditional floor trading. An electronic market has lower transaction costs due to low development and operating costs and lower implicit costs of trading (Domowitz, 2002). Empirically Jain (2005) shows that, based on the evidence from exchanges from 120 countries, electronic trading enhances liquidity and informativeness of stock markets. In turn, lower transaction costs and higher market efficiency are expected to enhance the ability of the exchange to attract foreign equity trading. Thus, exchanges that have introduced electronic trading platforms are expected to have better ability to attract foreign equity trading compared to (a) prior to the implementation of electronic trading, and (b) other exchanges that utilize floor trading.

Fernandes and Giannetti (2009) argue that market size measured by market capitalization of the host exchange, is a positive determinant of the probability of a foreign company listing on the exchange. The equity market size can be interpreted as a proxy for the size of the investor base and the level of equity market development. Markets that are relatively developed with larger investor base can facilitate market liquidity and, consequently, are likely to attract equity trading of

market of the Deutsche Borse, including the Frankfurt and XETRA exchanges, and VIRTX, the trading platform of the Swiss stock exchange. Often companies are not aware that their stocks are traded on such markets. 
foreign stocks. Thus, larger markets are expected to have superior ability to attract foreign equity trading.

The probability of listing on a foreign exchange is positively related to the level of liquidity of the foreign exchange and negatively related to the level of liquidity of the home exchange (Fernandes and Giannetti, 2009). Market liquidity measures the market depth and, thus, is a proxy for an exchange's importance and market power (Serifsoy, 2008). Thus, exchanges that offer a higher level of aggregate market liquidity are expected to have a stronger competitive position in attracting foreign equity trading.

When a stock is traded on several exchanges with different levels of trading costs it is reasonable to expect that order flow will migrate to the exchange that offers the lowest costs of execution. Thus, exchanges that offer lower costs of trading are expected to have superior ability to attract foreign equity trading.

\section{Host country characteristics}

The quality of the legal environment relevant to equity trading is determined by the level of investor protection and enforcement of insider trading legislation in the country. Weak legal investor protection in the country empowers corporate managers to seize private benefits of control and, accordingly, increases the costs of owning and trading stocks for investors and, particularly, for foreign investors who do not understand how the local system works (Shleifer and Vishny, 1997). When a stock is traded on more than one market with different levels of investor protection, the rational expectation is that investors would choose to trade on a market where they are better legally protected. Thus, host markets that offer better legal protection to investors are expected to have superior ability to attract foreign equity trading.

Another important consideration for traders is legislation regarding insider trading. The principal aim of insider trading regulation is to prevent insiders with an information advantage from trading at the expense of other traders (Durnev and Nain, 2007). Numerous studies on the benefits of prohibiting insiders from trading argue that regulation reduces the amount of trading based on private information (Durnev and Nain, 2007), decreases adverse selection costs for market participants (Fisher, 1992), improves investor confidence by providing incentives for corporate managers to disclose information (Maug, 2002), and enhances stock price informativeness and market liquidity (Fernandes and Ferreira, 2009; Beny, 2005). Furthermore, Bhattacharya and Daouk $(2002,2009)$ suggest that the introduction of the regulation itself is not 
sufficient. It is the enforcement of insider trading laws, rather than their mere existence, that actually brings positive consequences to capital markets. Thus, host markets that have better enforcement of insider trading laws are expected to have superior ability to attract foreign equity trading.

In order to minimize the costs of obtaining reliable information about the stock, investors would choose to trade on a market with a better information environment, in line with theoretical predictions of Huddart et al (1999). Thus, host markets with lower levels of accounting opacity are expected to have superior ability to attract foreign equity trading.

\subsection{Stock-level factors of foreign equity trading}

A stock with particular characteristics is likely have a different level of trading activity depending on the location of trading. We examine whether major exchanges specialize in different types of stocks and expect that sensitivity of stock-level factors of foreign trading volume varies across host exchanges. Stock-level factors that potentially affect the distribution of equity trading volumes include: 1) listing characteristics, 2) company characteristics, and 3) home market characteristics.

\section{Listing characteristics}

Although some of the listing characteristics that potentially affect the fraction of trading on a foreign exchange have been considered in previous studies (Pulatkonak and Sofianos, 1999; Sabherwal, 2007), the majority of listing characteristics examined in this study are unique and became available for examination due to the novelty of the sample consisting of European stocks traded on various exchanges.

A foreign account in the sample is classified as 'listed' if the stock is listed and traded on the exchange where it is listed, and is classified as 'traded' if the stock is traded on an OTC market or alternative markets where it is admitted to trade. In line with argument on the ability of regulated vs. non-regulated markets to attract equity trading (section 2.1), listed accounts are expected to have a higher share of foreign trading volume compared to traded accounts.

Arguably, the incremental increase in the investor base is largest for the first foreign listing. Empirically, Sarkissian and Schill (2009) find that a first foreign listing has a more profound impact on corporate valuation than subsequent foreign listings. Thus, the first foreign 
exchange listing is expected to generate a higher share of foreign trading volume compared to consequent foreign listings.

Existing empirical evidence on the effect of duration of listing on volume of trade is contradictory. Pulatkonak and Sofianos (1999) report a positive but insignificant impact of the duration of listing on the US share of trading volume whereas Halling et al (2008) find that foreign trading volume decreases with the time elapsed since cross-listing, meaning trading of cross-listed stocks eventually migrates back to the home market. However, Chordia et al (2007), argue that the duration of listing is a proxy for stock's visibility to investors and, thus, is expected to have a positive relationship with the stock's trading volume on this exchange.

Pulatkonak and Sofianos (1999) argue that non-US stocks with a higher US dollar price have a larger US share of trading volume larger the minimum tick size in New York than that on the home market. Chordia et al (2007) report that stocks with higher price level, experience higher turnover, consistent with Brennan and Hughes (1991) who show that trading costs are inversely related to price per share. Thus, stock price level is expected to be a positive determinant of the stock's share of foreign trading volume.

When equity trading in the home and host markets takes place in the same currency, splitting orders between markets is easier for investors as they bypass currency exchange risk and avoid the extra costs involved in converting local currency into a foreign currency. Thus, foreign trading of stock is expected to be more active when it takes place in the same currency as the home market trading.

Foreign listing can take place in the form of ordinary shares as well as in the form of depository receipts (DRs). ${ }^{9}$ For US investors ADRs (American DRs) trading could be preferable to trading ordinary shares in the issuer's home market because ADRs trade, clear and settle according to international conventions and offer quotes and dividends in US dollars. On the other hand, trading ADRs could be more expensive than trading ordinary shares as generally, the Depository bank charges a per share fee for every share purchased or sold and for dividends accrued. Arguably, the higher costs of trading outweigh the convenience of trading depository receipts.

\footnotetext{
${ }^{9}$ Often the DR conversion ratio, i.e. the number of underlying shares represented by a single depository receipt is different from one, making the price of a DR differ from the price of the underlying stock.
} 


\section{Company characteristics}

Larger companies have greater visibility to investors because they release more public information, experience more intensive media attention, have larger advertising budgets and a greater number of analysts following (Bhushan, 1989; Aggarwal et al, 2005), and, consequently, have more active trading of their stocks. Even though Kang and Stulz (1997) and Aggarwal et al (2005) report that larger companies have a greater fraction of equity owned by foreign institutional investors, it is not clear whether trading activity in stocks of larger companies would be driven abroad after cross-listing to a higher degree than trading activity in stocks of smaller companies. The trading of stocks of larger companies is usually anchored in the home market to a higher degree due to the presence of a more established investor base and a strong analyst following. In line of this argument, stocks of smaller (larger) companies are expected to have higher (lower) share of foreign trading.

Another commonly used proxy for stock visibility is the company's growth opportunities (Chordia et al, 2007). In addition, a company's growth could signal that the company needs to raise capital. Raising capital on a foreign exchange increases the probability of having a larger investor base and more active equity trading on the foreign exchange. Thus, higher-growth stocks have a higher share of foreign trading.

Export-oriented companies are more visible to foreign investors due to their presence on the product market of the foreign country. Accordingly, stocks of companies with a higher fraction of foreign sales are expected to have a higher share of foreign trading. Institutional investors are likely to supply liquidity and encourage trading activity by other market participants in the market where they operate (Halling et al, 2008). Thus, stocks with higher foreign institutional ownership should have a higher share of foreign trading.

The presence of controlling shareholders limits the ability of portfolio investors to hold the stock (Dahlquist et al, 2003). Further, concentrated stock ownership is inversely related to stock liquidity (Heflin and Shaw, 2000; Rubin, 2007). Additionally, high ownership concentration could signal poor governance and poor minority investor protection (La Porta et al, 2000). Thus, stocks with higher ownership concentration are expected to have a smaller share of foreign trading.

Stocks with higher stock price volatility have a higher level of uncertainty about fundamental values. In turn, higher levels of prediction error and rebalancing needs of investors would generate higher trading activity in the stock (Chordia et al, 2007). Halling et al (2008), 
interpret stock return volatility as a measure of stock sensitivity to new information. Accordingly, riskier stocks are expected to have a higher share of foreign trading.

Higher levels of transparency boost investor confidence due to the increased certainty about fundamental corporate values. Transparency at company level can be measured by the quality of the accounting standards used by the company. Adopting enhanced accounting disclosure standards, such as international accounting standards (IAS) or US GAAP, could be a way to overcome the home country's institutional deficiencies, particularly for companies from developing countries (Aggarwal et al, 2005). Stocks of companies that have adopted internationally recognised accounting standards are expected to have a higher share of foreign trading.

Foreign investors should find stocks that exhibit low correlation of returns with the foreign market index returns appealing due to potential portfolio diversification benefits. Accordingly, stocks that exhibit lower levels of correlation of returns with the foreign market returns should have a higher share of foreign trading.

Baruch et al (2007) argue that the trading volume of internationally cross-listed stocks is higher on exchanges in which the cross-listed stock returns have a higher level of correlation with returns of other assets traded on that market. They show that the most important determinant of the distribution of trading volumes of stocks cross-listed in the US, is the US information factor, a measure of the incremental contribution of the US market in explaining stock's return. In line with this argument, stocks with a higher foreign information factor should have a higher share of trading on the relevant foreign market.

\section{Home country characteristics}

Home countries in the sample exhibit significant differences in their level of economic development, the maturity of their legal systems, their accounting practices, the level of transaction costs, and their cultural and geographic proximity. These differences can potentially explain the variation in the foreign trading volume share of cross-listed stocks. Baruch et al (2007) argue that due to the presence of regulatory constraints and higher overall trading costs in emerging countries, stocks from emerging countries should have higher foreign trading turnover. Thus, stocks from emerging markets should have a higher share of foreign trading.

As discussed above, markets with enhanced investor protection and enforced insider trading regulation have a competitive advantage in attracting foreign equity trading. Thus, 
enhanced legal investor protection and enforced insider trading regulation in the home country should help to retain trading of cross-listed stocks on the home market.

Corporate transparency is greatly affected by the quality of accounting standards practised in the company's country of origin. The accounting opacity of the home country is an additional risk factor for foreign investors as it increases valuation uncertainty due to the poor quality and unreliability of accounting information. Thus, it should be negatively related to the attractiveness of the stock to foreign investors (Aggarwal et al, 2005). Markets that offer lower costs of trading to investors have a competitive advantage in attracting foreign equity trading. Thus, higher trading costs in the home market push the trading of cross-listed stocks away from the home market towards markets with lower costs of trading.

Sarkissian and Schill (2004) argue that a common language between countries is a proxy for cultural proximity as it often results from shared historical background and cultural proximity and is thus an important determinant of across-listing decision. Along similar lines, Grinblatt and Keloharju (2001) find that investors are more likely to trade stocks of companies that communicate in the investor's native language. Language differential, meaning information barriers between home and foreign markets, gives home market traders an informational advantage over foreign markets traders under the assumption that most price-sensitive information is generated in the company's home market. Thus, host market should attract trading of cross-listed stocks more easily when the host and home markets share a common language.

Geographic distance can be interpreted as a measure of stock's unfamiliarity to foreign traders. ${ }^{10}$ Grinblatt and Keloharju (2001) show that investors' equity trading activity is negatively related to the distance between the investor and the company's headquarter. Also, the distance between capital cities is the main negative determinant of cross-border equity flows (Portes and Rey, 2005). In addition, Sarkissian and Schill (2004) argue that corporate cross-listing decisions exhibit a 'proximity bias' meaning that companies tend to cross-list in geographically-approximate markets. Thus, stock's foreign trading volume share is expected to be inversely related to the geographic distance between host and home countries.

\footnotetext{
${ }^{10}$ Geographic distance between the host and home countries is closely related to the difference in time zones between the host and home countries. According to Pulatkonak and Sofianos (1999), the time zone difference is the most significant determinant of foreign trading volume on NYSE. However, in the case of the European stocks traded within continental Europe, the time zone difference is not relevant as all continental Western European countries (with the exception of Portugal) are in the same time zone.
} 


\section{THE SAMPLE AND DATA}

The sample

The sample consists of European companies that have had their stock cross-listed on at least one foreign stock exchange. The sample starts from 1990 and ends in December 2007. The sample is guided by the availability and quality of data at the time of data collection. The crosslisting sample is compiled from the stock exchanges' web-sites, Factiva news database and foreign listings dataset of Sarkissian and Shill $(2004,2009)$. Data on depository receipts is compiled from the BNY, Citibank, Deutsche Bank and JP Morgan DRs databases available on-line. Additionally, the stock should have been listed in the home market to enter the sample, i.e. direct foreign IPOs are excluded. The analysis is performed on the security level rather that the company level: all related listings for each cross-listed stock are identified by ISIN (data source: Datastream). Underlying ISINs and depository receipts conversion ratios for depository receipts are from the above mentioned Depository receipts (DRs) databases. Only common equity and major securities are included in the sample.

The final sample consists of 795 companies from 25 different countries with 2,853 foreign accounts. Foreign accounts in the sample include stock exchange listings, OTC, and admitted to trade accounts. In total there are 39 foreign exchanges in the sample. However, out of 39 exchanges only eleven exchanges attract more than $90 \%$ of the foreign trading volume of European crosslisted stocks in the sample. Those stock exchanges are: the NYSE, NASDAQ, US OTC, the London stock exchange, Paris, Amsterdam, Milan, Frankfurt, XETRA, the Swiss stock exchange and VIRTX. ${ }^{11}$ Datastream is the main source for company specific data such as stock price, number of shares traded total return index, market capitalization, price-to-book ratio, fraction of foreign sales and ownership structure.

Average foreign trading volume share: calculation

The ability of a stock exchange to attract foreign equity trading is measured by the exchange's monthly average foreign trading volume share (AFTVS) which is calculated as the

\footnotetext{
${ }^{11}$ Each of these eleven exchanges attracts at least $2 \%$ of the total equity trading volume of the sample stocks with the exception of the Deutsche Borse's XETRA and the Swiss stock exchange's VIRTX trading platforms that are included in the analysis of the major host exchanges for two reasons. First, they are integral parts of the larger exchanges: the Deutsche Borse and the Swiss stock exchange respectively. Second, the number of the accounts in the sample on these the exchanges are highly significant. Thus, in $2007,18.7 \%$ of all the account-month observations are contributed by XETRA and $5.8 \%$ by VIRTX.
} 
average of the trading volume shares of all foreign stocks traded on the exchange in each month as in equation (1):

$$
\operatorname{AFTVS}_{n}=\left(\Sigma^{N}{ }_{n=1} F T V S_{i, n}\right) / N
$$

where, $F T V S_{i, n}$ is the stock $i$ 's foreign equity trading volume share on the exchange $n$ in month $t$; $N$ is the number of stocks traded on the exchange $n$ in month $t$.

A stocks' trading volume share on a particular foreign exchange $\left(F T V S_{i, n}\right)$ is calculated as the ratio of the number of shares traded on the exchange to the total number of the shares traded in the same month on all exchanges/ trading venues in the sample as in equation $(2)^{12}$ :

$$
\operatorname{FTVS}_{i, n}=N S T_{i, n} /\left(\Sigma^{N}{ }_{n=1} N S T_{i, n}\right)
$$

where, $N S T_{i, n}$ is the number of shares of stock $i$ traded on the exchange $n$ in month $t$.

\section{Average foreign trading volume share: summary statistics and time trends}

Panel A of Table II reports the average foreign trading volume share (AFTVS) for the total sample that consists of the pooled sample and also individually for eleven major stock exchanges. Figure 1 graphically presents the AFTVS and the number of account-month observations by year, both for the total sample and individually for the eleven exchanges.

The AFTVS for the total sample is $11.9 \%$. London's AFTVS (mean 36.6\%), the highest among the eleven exchanges, reached its maximum of $38.2 \%$ in $1999 .{ }^{13}$ NASDAQ's AFTVS (mean 29.2\%), the second highest in the sample, has been relatively stable across the years with a maximum of $36.7 \%$ in 2007 . The NYSE's AFTVS is above the sample's average: $15.5 \%$ with a maximum of $17.2 \%$ in 1996 . The US OTC's AFTVS is $9.7 \%$ and it has shown a clear downward trend over the years: it was at its peak of $30.2 \%$ in 1990, has been declining ever since. Amsterdam's AFTVS is $34.9 \%$ with a maximum of $24.6 \%$ in $1997 .{ }^{13}$ Both Amsterdam and Paris stock exchanges, part of Euronext group, have seen an improvement in the AFTVS in 2005-2007. Paris's AFTVS has been steadily increasing and reached a maximum of $10.3 \%$ in 2007 (with the

\footnotetext{
${ }^{12}$ For example, the Bank of Ireland stock (ISIN: IE0030606259) in 2007 had total trading volume of 18,714 million GBP, including 7,896 million GBP on the home exchange Dublin, and the rest 10,819 million GBP on foreign exchanges, referred to as the foreign trading volume in this study. Foreign trading volumes were contributed by trading on the London stock exchange (10,368 million GBP), on NYSE (446 million GBP), on the Frankfurt stock exchange ( 3 million GBP) and on the US OTC market ( 2 million GBP). Thus, the Bank of Ireland stock's foreign trading volume share on the London stock exchange in this example is 55\% $(=10,368 / 18,714)$, on NYSE $2 \%$, on Frankfurt and US OTC market less that $1 \%$.

${ }^{13}$ Observations prior to 1995 are excluded because of small number of observations and, thus, should be treated with caution.
} 
historical mean of 2.9\%). Milan's AFTVS is $6.9 \%$ with significant fluctuations over time from $16.1 \%$ in 2005 to $1.9 \%$ in 2007.

The exchanges of Deutsche Borse, Frankfurt and XETRA, both have AFTVSs of around $2 \%$, significantly below the sample average and this has been steadily low across the years. Similarly, the Swiss stock exchange and VIRTX have low AFTVSs of $2.9 \%$ and $0.2 \%$ respectively. The VIRTX's share has been low since 2001, when the exchange was introduced. On the other hand, the Swiss stock exchange seems to have lost the ability to attract trading volumes of foreign European stocks over time: it had its maximum foreign trading volume share of $8.8 \%$ in 1996 and ever since its share has been declining and went as low as $0.1 \%$ in 2007 .

Regarding the number of observations contributed by stock exchanges, Deutsche Borse's exchanges Frankfurt and XETRA stand out from the other exchanges by the number of the accounts they host, particularly in the most recent period: on average, $19.2 \%$ and $12.4 \%$ for Frankfurt and XETRA respectively. The majority of these accounts represent admissions to trade rather than listing. Despite the significant number of trading accounts, Deutsche Borse and, similarly, the Swiss stock exchange' VIRTX struggle to attract and maintain active trading of foreign stocks.

\section{Explanatory variables}

Two major sets of determinants of the foreign trading volume share in this study are host exchange/country specific (pull) factors of foreign trading and stock-level factors, such as listing characteristics, company characteristics, and home market characteristics. Table I identifies empirical measures for each of the potential determinants. Appendix A presents detailed definitions and data sources of all the explanatory variables.

\section{Pull factors of foreign equity trading: summary statistics}

Panel B of Table II reports summary statistics of the pull factors for the pooled sample and individually for the eleven stock exchanges. Around $11 \%$ of the observations are traded accounts (i.e. traded on the US and London OTC markets, VIRTX and XETRA trading platforms). Almost half of the sample stocks are traded on a demutualised exchange. Indeed, by the end of the sample period all major host exchanges in the sample had been demutualized. The lowest mean demutualization indicator is for the NYSE, which was only demutualized in 2006. On average, $80 \%$ of the observations take place on an electronic market as opposed to the traditional floor 
trading. The lowest electronic market indicator is for the NYSE, which in 2000 was among the last exchanges in the world to introduce automated trading. After 2002 all exchanges in the sample, both of host and home markets, had adopted electronic trading.

The US market stands out through its market size in terms of market capitalization of listed stocks $(5,157.4$ billion GBP), which is almost four times larger than the average market size in the sample $(1,299.0$ billion GBP), whereas Amsterdam has the smallest market size in the sample (261.7 billion GBP). The US market has the highest aggregate market liquidity of 100.04 on average (measured by the ratio of the aggregate monthly trading volume to the total market capitalization), followed by the Frankfurt stock exchange with a 93.06 turnover ratio. XETRA has the lowest level of liquidity in the sample with a turnover ratio of 36.96. Total trading costs vary from 0.47 on the Amsterdam stock exchange to 0.94 on the Swiss market with the sample average being 0.62 . The level of investor protection in the host country is highest in the UK (investor protection index is 0.95 ) and the lowest in the Netherlands (investor protection index is 0.20 ). About $80 \%$ of the stocks are traded in a country where insider trading regulations have been enforced. Italy has the highest level of accounting opacity (0.63), whereas the USA has the lowest level of accounting opacity ( 0.20$)$. The average size (market capitalisation) of a foreign company is smallest in NASDAQ (3.11 million GBP) and largest in VIRTX (18.56 million GBP).

\section{Stock-level factors of foreign equity trading: Summary statistics}

Table III reports summary statistics of stock-level factors of foreign trading for the 20032007 sample $^{14}$, for the pooled sample and individually for the eleven stock exchanges.

Listing characteristics. Average trading indicator is 0.71 reflecting the introduction of trading platforms in recent years. London is the most common choice for a first foreign listing by European companies in the sample: $12 \%$ of accounts are a first foreign listing compared to a $2 \%$ sample average. The average age of an account in the sample is 6.24 years $^{15}$; the oldest are the Swiss stock exchange's accounts (12.72 years). Trading on the US exchanges and the Swiss stock exchange takes place exclusively in the currency of the host market, while trading on VIRTX takes place in the currency of the stock's home listing. Because of the adoption of the Euro, cross-border

\footnotetext{
${ }^{14}$ The reason for using the 2003-2007sample rather than the full sample is that data for two important explanatory variables related to stock ownership structure, foreign institutional ownership and ownership concentration, are available from Datastream database only from 2003.

${ }^{15}$ Average duration of London listing/trading in the sample is relatively short (4.64 years). This can be explained by the changes in trading systems which resulted in the disruption of continuous listing, rather than a true reflection of the actual duration of listing.
} 
trading in the Euro zone takes place in the same currency. In the sample, $27 \%$ of the accounts are in the form of depository receipts (DRs). DRs are predominantly traded in the US. Frankfurt, XETRA and to a lesser extent London, accept DRs for trading as a supplement to trading ordinary shares. The average price level of European cross-listed stocks is 19.9 GBP with the lowest at 10.6 GBP for NASDAQ-traded and the highest at 33.2 GBP for Swiss stock exchange-traded stocks.

Company characteristics. The average market value of a cross-listed stock is 15.3 billion GBP. The smallest and the riskiest foreign stocks in the sample are traded on NASDAQ. The Swiss stock exchange and VIRTX attract trading of large, low-risk foreign stocks. The NYSE and NASDAQ trade stocks that have the highest relative market valuation measured by a price-to-book ratio, of 4.83 and 3.21 respectively, both above the sample's average of 3.07. On average, the fraction of foreign sales in the company's total sales is $57 \%$ reflecting the strong export orientation of cross-listed companies. NASDAQ-traded companies have the highest foreign sales share (68\%). Foreign institutional ownership is $8 \%$. Ownership concentration is $26 \%$ for the sample varying from $11 \%$ for Milan-traded stocks to $30 \%$ for Frankfurt-traded stocks. The use of international accounting standards is common among cross-listed companies ( $73 \%$ mean). The Swiss stock exchange and VIRTX only trade stocks of companies that comply with international accounting standards requirements. The sample's average stock return correlation with foreign market return is 0.48. The sample's average foreign information factor is 2.62 with the smallest being for VIRTXtraded stocks (1.47) and the largest for Amsterdam-traded stocks (3.64).

Home market characteristics. $2 \%$ of observations in the sample are contributed by stocks that originate in the emerging markets of Central and Eastern Europe. The highest average emerging market indicator in the sample is for Frankfurt's observations (4\%). The average investor protection index of the home market is 0.48 . For $91 \%$ of observations insider trading laws are enforced in the home country. The average trading costs in home countries are the highest for London's accounts and the lowest for VIRTX's accounts. Stocks from countries with the lowest level of accounting opacity are traded on the Swiss stock exchange (0.24), while stocks from countries with the highest level of accounting opacity are traded on the Frankfurt and XETRA exchanges (0.36).

Pull factors at stock level. In addition to the listing characteristics, company characteristics and home market characteristics Table III reports summary statistics of pull factors calculated at stock level that reflect the difference between the host and home market characteristics. On average 
a host market is 9.91 times larger than a home market. The largest difference in market size is 41.39 for NASDAQ accounts. Aggregate market liquidity of the host market is on average 5.2 times higher than the market liquidity of the home market. For the Swiss stock exchange the difference in market liquidity between the host and home markets is the highest (19.4 times). A negative average difference in trading costs between the host and home markets implies that, on average, costs of trading on the host market are lower than costs of trading on the home market. London offers the best improvement in total trading costs, while VIRTX has the highest trading costs relative to the home market. The negative sample's average difference in the level of investor protection between the host and home countries implies that home markets, on average, have somewhat better investor protection than host markets. At the same time, host countries in the sample have insider trading laws enforced more often than home countries. London has the highest improvement both in the level of investor protection and in insider trading law enforcement. The level of accounting opacity in a home country is, on average, higher than the level of accounting opacity in the host country. Around $22 \%$ of all observations in the sample are for accounts that are traded abroad in the same language environment as the home country. The highest common language indicator is for the Swiss stock exchange and NASDAQ's accounts. The average geographic distance between home and host markets is around 2,000 km, driven by the distance of European home markets from the US (average geographic distance to a US exchange is above 6,000km). Within Europe, the average geographic distance between home and host markets varies within a $534-1,183 \mathrm{~km}$ range.

\section{Listed vs. traded accounts: summary statistics}

Additionally, Table III reports summary statistics separately for listed and traded accounts. Listed companies are larger than those admitted to trade (18.2 vs. 14.0 billion GBP), are listed on a foreign exchange for a longer period of time ( 8.26 years vs. 5.42 years), are more likely to list in foreign country that shares a language with the home country (common language indicator 0.34 vs. 0.17 ), and are more likely to list in a country that is further away from the home country (geographic distance 2,283 km vs. 1,974 km).

\section{THE RESULTS}

This section reports the results of the analysis of the determinants of foreign trading volume share (a) at stock exchange level (pull) factors and (b) at stock level factors. Regression 
analysis is used to test the hypotheses on the potential determinants of the foreign trading volumes share outlined in section II and summarized in Table I. The regressions are estimated using OLS procedure with heteroskedasticity consistent (White, 1980) standard errors to account for the possible correlation within a cluster. ${ }^{16}$

\subsection{Pull factors of foreign equity trading}

Pull factors of foreign equity trading are evaluated using the following regression:

$$
\log \operatorname{trAFTS}_{n}=\alpha_{0}+\Sigma \theta_{k} Z_{k, n}+C_{n}+\varepsilon_{n}
$$

where $\log t r A F T V S_{n}=\ln \left(A F T V S_{n} /\left(1-A F T V S_{n}\right) ; A F T V S_{n}\right.$ is average foreign trading volumes share of host exchange $n$ in month $t ; Z_{k, n}$ is characteristic $k$ of host market $n$ in month $t$, and $C_{n}$ is average size of companies traded on host exchange $n$ in month $t$ (control variable). The explanatory variables are defined in Appendix A. Table V reports the outputs of this regression. Model 1 includes stock exchange-specific factors, whereas models 2-5 additionally include host country characteristics, such as the level of investor protection, enforcement of insider trading laws and accounting opacity index. As a robustness tests, model 3 is estimated with year fixed effects, model 4 is estimated with exchange-fixed effects and includes OTC, VIRTX and XETRA indicators but excludes the demutualization indicator that is not available for OTC observations.

In line with the theoretical expectations, non-regulated markets trading platforms have, on average, a lower AFTVS compared to the stock exchange: coefficient estimates on the trading platform variable are negative in all model specifications. Model 4 includes, instead of the trading platform indicator, OTC, VIRTX and XETRA indicators that have negative coefficient estimates. In line with the theoretical argument that demutualized exchanges are more efficient, the demutualization variable has positive and significant coefficient estimate in models 1 and 2 . However, after controlling for time effects in model 3, the demutualization variable is not statistically significantly different from zero. In contrast to expectations that automated trading provides a competitive advantage to a stock exchange in attracting trading volumes, the electronic market indicator has a negative and statistically significant coefficient estimates. ${ }^{17}$ A possible

\footnotetext{
${ }^{16}$ Petersen (2009) compares a number of approaches for estimating standard errors in panel data sets where the residuals may be correlated cross-sectionally and across time, and concludes that in the presence of a firm fixed effects (which is the case in this study) only clustered standard errors are unbiased.

${ }^{17}$ In contrast to literature that supports the higher efficiency and lower costs of electronic vs. floor trading argument (Domowitz, 2002; Jain, 2005), Venkataraman (2001) reports higher trading costs on the electronic market (Paris) vs. floor trading (NYSE) and suggests that 'there is a benefit to human intermediation in the trading process' (p.1448).
} 
explanation for the negative sign of the electronic market indicator is that electronic markets in the sample are overrepresented by trading platforms. It is possible that the electronic market indicator actually reflects the lesser ability of trading platforms to attract foreign equity trading.

Market size is a positive and significant determinant of the AFTVS (model 1). However, after controlling for host country characteristics it becomes insignificant. As expected, markets with a greater level of aggregate liquidity are more successful in attracting active trading of foreign stocks: the coefficient estimates on the market liquidity variable are positive and highly significant in all model specifications. Higher transaction costs are expected to be a significant competitive disadvantage in attracting trading to the exchange. Indeed, the regression analysis reveals that total trading costs in the host market is a negative and statistically significant determinant of an exchange's average fraction of foreign equity trading.

The quality of the legal environment in the host country is expected to have a positive impact on the stock exchange's ability to attract foreign equity trading. Analysis reveals that enforcement of insider trading laws in the host country is positive and significant determinant of the AFTVS. The level of investor protection is a positive, although, statistically insignificant factor. As expected, accounting opacity in the host country has a negative impact on the stock exchange's ability to actively trade foreign stocks: coefficient estimate on the accounting opacity index is negative and significant. A control variable, average company size, is a highly significant (at $1 \%$ significance level) and negative determinant of the AFTVS.

\section{Multicollinearity issue}

There is legitimate concern that the exchange-level explanatory variables are correlated. A correlation matrix of the pull factors (Table IV) shows that the correlation coefficients are within an acceptable range (0.42-0.56). Additionally, we estimate variance inflation factors (VIFs) (not reported). The estimated VIFs are within the range of 1.08 to 4.18 indicating that multicollinearity should not affect the findings in any significant way. ${ }^{18}$

\section{Pull factors: Economic significance}

Since the regression analysis uses the logistic transformation of the dependent variable, the interpretation of the estimated coefficients is not straight forward. To overcome this issue, the relative importance of variables is approximated by the economic significance of coefficient

\footnotetext{
${ }^{18}$ Sabherwal (2007) points out that multicollinearity is likely to be an issue only if a VIF is above 10.
} 
estimates. ${ }^{19}$ Table V reports the economic significance of the coefficient estimates for model 2. Average company size is the most significant determinant of the average fraction of foreign equity trading (with the economic significance of $42 \%$ ). This result highlights the importance of companyspecific factors for trading volume distribution and motivates stock-level analysis (discussed in forthcoming section 4.2). The other significant determinants of the AFTVS are: electronic market trading ( $35 \%$, negative impact), total trading costs $(29 \%$, negative impact), trading on a demutualized exchange ( $25 \%$, positive impact), and enforcement of insider trading laws in the host country $(24 \%$, positive impact).

Overall, the results have shown that stock exchange characteristics, or the pull factors of foreign trading volume, are significant determinants of a stock exchange' average foreign trading volume share, which is the measure of a stock exchange's ability to attract order flow of foreign stocks. The following stock exchange characteristics significantly affect a stock exchange's ability to compete for foreign equity trading: costs of trading, the level of accounting opacity, demutualization, market-level liquidity, and the enforcement of insider trading laws.

\subsection{Stock-level factors of foreign equity trading}

The second group of potential determinants are stock-specific factors. Dependent variable in the stock level analysis is the logistic transformation of the foreign share of equity trading volume, which is calculated for each stock as the ratio of the number of shares traded on the exchange to the total number of the shares traded in the same month on all exchanges/ trading venues in the sample. ${ }^{20}$ The hypothesis is that stock-level factors, along with the pull factors, significantly affect the distribution of foreign equity trading volume of cross-listed stocks. Regression specification is as follows:

$$
\log \operatorname{trFTVS} S_{i, n}=\alpha_{0}+\sum \gamma_{j} X_{j}+\sum \theta_{k} Z_{k, n}+\varepsilon_{i, n}
$$

\footnotetext{
${ }^{19}$ Economic significance of coefficient estimates is calculated following the methodology of Welch (2004) and Bris et al (2007). Economic significance indicates the percentage standard deviations of the dependent variable explained with a one standard deviation change in the explanatory variable. It is calculated as a ratio of the product of the coefficient estimate and the standard deviation of the variable in the sample, termed the unit-normalized coefficient, to the standard deviation of the dependent variable (Bris et al, 2007). Importantly, the economic significance is comparable across explanatory variables.

${ }^{20}$ It is an innovative way to calculate foreign trading volume share as that it takes into account trading activity on all the venues where a stock is being traded (subject to data availability). In contrast, the calculation of the US fraction of trading in previous studies (Baruch et al, 2007; Halling et al, 2008) ignores trading on markets other than the stock's home market and the US market. Furthermore, using the number of shares traded for the calculation of foreign trading volume share rather than the dollar value of equity trading, as in Halling et al (2008), eliminates potential bias in the findings due to the currency exchange rate fluctuations.
} 
where $\log \operatorname{trFTVS} S_{i, n}=\ln \left(F T V S_{i, n} /\left(1-F T V S_{i, n}\right)\right), F T V S_{i, n}$ is the stock $i$ 's foreign equity trading volume share on the exchange $n$ in month $t ; X_{j}$ is vector of stock-level factors; $Z_{k, n}$ is characteristic $k$ of the host market $n$ or characteristic $k$ of the host market $n$ relative to characteristic $k$ of the stock's home market.

Moreover, the sensitivity of the stock-level determinants is expected to vary depending on the trading venue. To test this hypothesis the loadings of the explanatory variables are estimated individually for the major exchanges by introducing interaction variables of a stock exchange dummy variable with the explanatory variables, stock-level factors:

$$
\begin{aligned}
\operatorname{logtrFTVS} S_{i, n}= & \alpha_{0}+\sum \gamma_{j, \text { Listed }}\left(D_{\text {Listed }} X_{j}\right)+\Sigma \theta_{k, \text { Listed }}\left(D_{\text {Listed }} Z_{k, n}\right)+\sum \gamma_{j, \text { Traded }}\left(D_{\text {Traded }} X_{j}\right)+ \\
& +\sum \theta_{k, \text { Traded }}\left(D_{\text {Traded }} Z_{k, n}\right)+\varepsilon_{i, n}
\end{aligned}
$$

where $D_{\text {Listed }}$ is dummy variable that equals one if the stock is listed on a stock exchange $n$ in month $t$ and equals zero otherwise, $D_{\text {Traded }}$ is dummy variable that equals one if the stock is traded without meeting listing requirements on a stock exchange $n$ in month $t$ and equals zero otherwise.

Table VI reports the regression outputs. Model 1 includes stock-level factors that proxy the stock's listing characteristics, company characteristics and home market characteristics, as discussed in section 2.2. Model 2 includes interaction variables of the explanatory variables with the dummy variables that represent the eleven major host exchanges, namely, the NYSE, NASDAQ, US OTC, the London, Swiss, Frankfurt, Paris, Amsterdam, Milan stock exchanges and VIRTX and XETRA trading platforms. The explanatory variables are defined in Appendix A.

\section{Listing characteristics}

Table VI shows that the most significant group of stock-level factors are the listing characteristics that are all found to be statistically significant determinants of the FTVS (model 1). Firstly, traded status, as opposed to listed status, substantially reduces the fraction of trading on the foreign exchange: the coefficient estimates on the traded indicator in all models are negative and significant. Thus, a corporate decision to list on a foreign exchange, as opposed to having a stock admitted to trade, although it entails additional listing requirements, guarantees more active foreign trading of stock. Specifically, traded accounts of the Frankfurt and XETRA exchanges have significantly smaller FTVS than listed accounts (model 2). 
Coefficient estimates on the first foreign listing indicator, the duration of the listing and the same currency indicator variables are also positive and significant (model 1). Accordingly, the findings confirm that FTVS is significantly higher when a company is listed abroad for the first time, traded on a foreign exchange in the same currency as the home listing, and increases with the duration of listing. The duration of listing is particularly significant for XETRA and Frankfurt accounts (positive impact) but significant and negative determinant for VIRTX and Paris accounts. Coefficient estimates on the same currency indicator have positive signs for London, XETRA, and Frankfurt accounts but a negative sign for Milan accounts.

DR indicator, as expected, is a negative and significant determinant of the FTVS. However, DRs trading, as opposed to ordinary shares trading, generates significantly less active trading only on European exchanges (London, XETRA, and Frankfurt), whereas the difference in foreign trading volume share generated by listings in the form of ADRs and ordinary listings is insignificant for NYSE and NASDAQ listings and positive and significant for US OTC market listings. In line with the expectation that higher priced stocks are more visible to foreign investors, the coefficient estimate on the price level variable is positive in Model 1. Particularly, stocks with a higher price level have higher FTVSs when listed/traded on US OTC market, NYSE and Frankfurt, but smaller FTVSs when listed in Paris.

\section{Company characteristics}

The coefficient of company size is a negative and significant (model 1) suggesting smaller companies have a significantly larger FTVSs, in line with findings of Halling et al (2008) and Baruch et al (2007). Model 2 shows that smaller companies have higher significantly FTVSs when listed/traded in Milan, Amsterdam and US OTC market, whereas larger companies have significantly higher FTVSs when traded on VIRTX and XETRA. A company's growth (price-tobook ratio) has no significant effect on FTVS for the pooled sample (model 1). However, it is a positive and significant determinant in Milan and Amsterdam, and is a negative and significant determinant in NASDAQ, London, Frankfurt and XETRA accounts (model 2). Stock risk plays a positive and significant role in determining the FTVS (model 1). Moreover, it is a positive determinant in majority of the stock exchanges. Riskier stocks have particularly active trading on the Swiss stock exchange, Frankfurt stock exchange, XETRA, NYSE, and NASDAQ.

Company export orientation, measured by the fractions of foreign sales in total sales, as expected, is a positive determinant of the FTVS (model 1). However, the export orientation of a 
company is a positive predictor of the FTVS only when a stock is listed/ traded on the US exchanges, namely, NYSE, NASDAQ, and US OTC (model 2).

A higher fraction of foreign institutional ownership is expected to assure a FTVS, unless foreign institutional investors prefer to trade on the stock's home market. After controlling for home market characteristics that potentially affect the attractiveness of the home market relative to the host market as a location of the stock trading, foreign institutional ownership is a positive and statistically significant determinant of the FTVS (model 1). However, higher foreign institutional ownership assures a higher FTVS only for NYSE listings (Model 2). Ownership concentration, as predicted, has a negative impact on the FTVS, however, it is statistically insignificant for the pooled sample. Ownership concentration is a significant negative determinant only for NYSE listings (model 2).

Adopting IAS or US GAAP makes a company more transparent, comparable to other foreign companies, and, supposedly, more attractive to foreign traders (Aggarwal et al, 2005). However, we find no empirical support for this proposition for the pooled sample: coefficient estimate on the IAS variable is insignificant (model 1). Companies that have adopted international accounting standards have higher foreign FTVS, in line with expectations, when their stocks are traded on VIRTX, the Italian stock exchange, NASDAQ, the NYSE and the Paris stock exchange.

Due to potential portfolio diversification benefits, stock that exhibit a low return correlation with foreign market returns are expected to appeal to foreign investors. Indeed, empirical evidence supports this proposition: coefficient estimate on the return correlation with foreign market return variable is negative and significant (model 1), in line with evidence of Halling et al (2008). Furthermore, stocks that exhibit lower return correlations with foreign host market returns are more actively traded on NASDAQ, NYSE, and Frankfurt stock exchanges but significantly less actively traded on VIRTX.

According to Baruch at al. (2007), the foreign information factor that quantifies marginal contribution of foreign market returns in explaining the stock return pattern, is the main determinant of the FTVS. Correlation analysis (not reported) has shown that the US information factor and the foreign non-US information factor have opposite effects on the FTVS. Thus, these two variables are included in the regressions individually in place of the foreign information 
factor. ${ }^{21}$ In line with the findings of Baruch et al (2007), the US information factor is a positive and significant determinant of the FTVS. On the other hand, the coefficient estimate on the foreign non-US information factor is negative and significant. Thus, we find no empirical confirmation for the theoretical argument of Baruch et al (2007) for non-US host markets.

\section{Home market characteristics}

Emerging markets are characterised by higher investment barriers for foreign investors. Thus, cross-listed stocks of companies from emerging markets are expected to trade more actively on foreign exchanges. Indeed, coefficient of the emerging market indicator is positive significant (model 1), in line with findings of Baruch et al (2007) and Halling et al (2008). Particularly, stocks from emerging markets traded in London, Frankfurt and Paris and have more active foreign trading compared to stocks from developed markets. However, stocks from emerging markets have a smaller FTVS compared to stocks from developed markets on the US OTC market (model 2).

As predicted, the FTVS is higher when a stock is traded in a foreign country that shares a language with the company's home country as the coefficient of the common language indicator is positive and significant. Particularly, a common language between the home and host countries stimulates more active foreign equity trading for London, Frankfurt, and Swiss stock exchanges.

Geographic distance between the home and host countries is a proxy for foreign investors' unfamiliarity and, accordingly, expected to have a negative impact on the FTVS. Summary statistics of host market characteristics relative to home market (Table III) show that geographic distance from the US exchanges is very distinct from geographic distances from other host exchanges. Thus, it is possible that the geographic distance variable in the regressions captures the US-specific variation in the FTVS. To disentangle the US-specific variation, Model 1 includes, instead of the geographic distance variable, a dummy variable representing the US as the host market and a residual geographic distance variable, which is the residual from the OLS regression of the geographic distance variable on the US host market dummy. The coefficient of the US host market indicator is positive and significant. This can be interpreted as the 'US trading premium'. The coefficient of the residual geographic distance variable, in line with expectations, has a negative sign. Furthermore, geographic distance is a negative determinant for VIRTX, Paris, XETRA, and London accounts.

\footnotetext{
${ }^{21}$ In the model specification that incorporates the collective foreign information factor variable (not reported) the coefficient estimate on the foreign information factor is not statistically different from zero.
} 
Weaker investor protection and poor enforcement of insider trading laws in the home country are expected to drive the equity trading away from the home country to foreign markets where the stock is listed/ traded. Empirical evidence supports this proposition: the coefficient of the investor protection and the enforcement of insider trading laws in the home country dummy variables are negative and significant at the $1 \%$ level (model 1). Better investor protection in the home country is a positive determinant for Milan, Amsterdam and Swiss stock exchange listings and a negative determinant for London, Paris and VIRTX listings. Coefficient estimates on the enforcement of insider trading laws variable are around zero for all exchanges.

Higher trading costs in the home country are a significant disadvantage in competing with foreign exchanges for order flow. We find that the proxy variable for total trading costs in the home country is positive and significant (model 1), similar to results of Pulatkonak and Sofianos (1999) and Halling et al (2008). ${ }^{22}$ Stocks from markets with higher trading costs have higher FTVS in London and Amsterdam, but, unexpectedly, smaller FTVS on the Italian and Swiss stock exchanges.

Accounting opacity in the home country affects the perception of the quality of the company's accounting information and, thus, should negatively affect the stock's trading on a foreign exchange. For the pooled sample the coefficient estimate on the accounting opacity in the home country variable is insignificant (model 1). However, accounting opacity of the home country is a negative and significant determinant of the FTVS in Milan, VIRTX, Paris and NYSE.

To summarize, analysis of stock-specific factors of the foreign trading volume share provides evidence regarding which foreign market is more likely to provide active trading for a stock with particular characteristics. The US exchanges have more active trading in stocks of more export-oriented companies, the London stock exchange has active trading of stocks from emerging markets, from English-speaking countries and from countries with poor investor protection. VIRTX, in contrast, is most successful in generating equity trading of large foreign companies that comply with international accounting standards and come from countries with better investor protection and a better information environment.

\footnotetext{
${ }^{22}$ Halling et al (2008) used an indirect proxy for transaction costs in the home market, the level of financial development.
} 
Model 1 of Table VII reports the output of the regressions that include the significant determinants of foreign trading volume share from the multivariate analysis at stock level (Model 1, Table VI). Furthermore, it includes host market characteristics relative to those of home market. Accordingly, the host and home market characteristics, such as market size, market level liquidity, trading costs, investor protection, enforcement of insider trading laws, and accounting opacity, are substituted with the differences in these characteristics between the host and home markets. ${ }^{23}$ Also, Table VII reports for Model 1 the economic significance of the coefficient estimates. The US host market indicator that we interpret as the US trading premium is the most significant determinant of foreign trading volume share with economic significance of 55\%.

Listing characteristics are the most significant group of determinants that jointly explain the 0.70 standard deviations variation in the FTVS. The traded indicator variable is individually the most significant factor with economic significance of $24 \%$. Thus, change in status from traded to listed would increase the foreign trading volume share by approximately $2.65 \%{ }^{24}$, keeping other conditions constant. An increase of $2.65 \%$ in the foreign trading volume share is highly significant taking into account that the sample's average AFTVS is only about $3 \%$.

The other significant listing-specific factors are the duration of listing/trading and the same currency indicator variables with the economic significance of $19 \%$ and $18 \%$ respectively (positive contribution). The economic significance of the DR indicator is negative $6 \%$. Company size is the most significant company characteristics with an economic significance of $15 \%$ (negative contribution).

The variables that represent the difference in investor protection and the difference in enforcement of insider trading laws have positive and significant coefficient estimates. These findings are consistent with the theoretical argument that investors prefer to trade in countries that provide higher standards of investor protection and better enforcement of insider trading laws and are in line with empirical findings of Halling et al (2008) for the US fraction of foreign trading. The difference in the level of investor protection and in the enforcement of insider trading laws between the host and home countries jointly explain the $24 \%$ variation in the FTVS (positive contribution).

\footnotetext{
${ }^{23}$ None of the model specifications in Table VII include the difference in the demutualization status and in electronic trading because all stock exchanges in the sample starting from year 2003 have been demutualized and have adopted automated trading, making these two variables irrelevant for the 2003-2007 sample.

${ }^{24}$ Calculated as the product of the economic significance and the standard deviation of the independent variable.
} 
The difference in the market size has no significant effect. In contrast to expectations, the coefficient estimate on the difference in the aggregate market liquidity between host and home markets is negative and significant. This result is difficult to interpret as the theoretical models of Kyle (1985), Admati and Pfleiderer (1988), Pagano (1989) and Chowdhry and Nanda (1991) predict concentration of trading in the most liquid market. The difference in aggregate market liquidity has economic significance of $23 \%$ (negative contribution).

The coefficient of the difference in accounting opacity index between the host and the home countries is positive and significant. This finding can be interpreted as evidence that foreign investors trade more actively those foreign stocks that come from countries with a level of accounting opacity lower than that in the foreign country. The difference in the accounting opacity index has economic significance of $15 \%$ (positive contribution). The geographical distance between the host and home countries has an economic significance of 5\% (negative contribution). The economic significance of the US information factor is positive $4 \%$ and of the common language indicator is positive $8 \%$.

Overall, we find that stock-specific factors are significant determinants of foreign trading volume distribution. The next section discusses whether the determinants are different for stocks that are listed vs. stocks that are admitted to trade.

The determinants of the foreign trading volume share: Listed vs. traded

The nature of a foreign trading may vary significantly depending on whether the stock is listed on a foreign exchange or is admitted to trade. Model 2 of Table VII reports the output of regression of the stock-level FTVS on the interaction variables of the explanatory variables and the dummy variables that correspond to the listing or trading status.

Coefficient estimates of all the determinants have the same signs, meaning the direction of impact is the same, both for listed and traded accounts. The only exception is the difference in the trading costs, which is negative and significant for listed accounts and positive however insignificant for traded accounts. The level of statistical significance of the determinants for listed and traded accounts varies for some variables. Thus, stock risk, foreign institutional ownership, and the difference in the enforcement of insider trading laws are significant positive determinants for listed account but insignificant for traded accounts. Common language and the difference in investor protection and accounting opacity are significant positive determinants only for traded accounts. 


\section{CONCLUSIONS}

We examine the distribution of foreign trading volume of European cross-listed stocks and the factors that affect this distribution. We show that there are two main sets of determinants of foreign trading volume viz. the pull factors (i.e. host stock exchange/country specific factors) and the stock-specific factors.

Regarding the pull factors of foreign trading, we find that higher trading costs and a higher level of accounting opacity in the host country have a significant negative impact on the stock exchange's ability to attract active foreign equity trading. Furthermore, demutualized stock exchanges, stock exchanges with higher levels of liquidity and stock exchanges in countries with enforced insider trading laws have a superior ability to attract equity trading of foreign stocks.

In line with theoretical predictions of the Chemmanur and Fulghieri (2006) and Huddart et al (1999) that a foreign listing is beneficial due to the increase in investor awareness of the stock and the reduction in investors' monitoring costs we document that regulated markets are significantly more successful in attracting order flow of foreign stocks than non-regulated markets. Therefore, a stock exchange listing (as opposed to an admission to trade) on a foreign exchange, despite higher fees and disclosure requirements, should be regarded as a preferable option for companies that are looking to improve stock liquidity.

We consider three sets of the stock-level factors of foreign trading: listing characteristics, company characteristics, and home market characteristics. We find that the share of foreign trading increases over time. While this result is intuitively compelling as duration of listing/trading is the measure of stock visibility, it contradicts the findings of Halling et al (2008) that trading volumes of foreign stocks migrate back to the home market after the first year of cross-listing. Furthermore, company characteristics are important determinants of foreign trading volume share: foreign trading volume share is larger for smaller and riskier companies, for companies with higher foreign institutional ownership and with lower stock return correlation with host market returns. Foreign information factor that Baruch et al (2007) name as the main determinant of trading volume distribution is a positive determinant for the US listings but an insignificant determinant for nonUS listings.

Listing/trading on the US exchanges results in more active foreign trading compared to other host markets. We interpret this as the US trading premium of foreign trading volume share, 
similar to the US cross-listing valuation premium in Doidge et al $(2004,2009)$, which they justify by the fact that the US offers a deep and liquid capital market and a better-quality informational and legal environment. After disentangling the US-specific variation the geographic distance between the host and home markets, the measure of investors' unfamiliarity with the stock, is a negative and significant determinant of the foreign trading volume share, in line with 'home bias' in cross-listing decisions (Sarkissian and Schill, 2004) and 'home bias' in investments (Brennan and Cao, 1997; Grinblatt, and Keloharju, 2001).

The results also highlight the importance of the quality of the legal and information environments for the distribution of foreign equity trading. A market that provides better investor protection and has enforced insider trading laws has a strong advantage over other markets in attracting trading volumes of foreign stocks. Finally, the higher the quality of the information environment of the home market and, particularly, of the home market relatively to the host market, the higher the fraction of trading on the foreign exchange.

The findings have two important practical implications. First, for stock exchange executives it answers the question of which stock exchange characteristics determine a more favourable trading environment for foreign cross-listed stocks; in other words what makes a stock exchange more competitive in attracting foreign equity trading. Second, for corporate managers seeking to improve their company's stock liquidity, it answers the question of on which foreign stock exchange the company stock has the most potential to maximize its liquidity in terms of trading volume. 


\section{References}

Abee, S. and J. Zimmermann (2006). Do Cross-Listings Drive Regulatory Convergence? Evidence from Germany. University of Bremen Working paper.

Aggarwal, R. (2002). Demutualization and Corporate Governance of Stock Exchanges. Journal of Applied Corporate Finance, 15 (1): 105-113.

Aggarwal, R., L. Klapper and P. D. Wysocki (2005). Portfolio Preferences of Foreign Institutional Investors. Journal of Banking and Finance, 29 (12): 2919-2946.

Baruch, S., Karolyi, G. A. and Lemmon, M. (2007). Multi-Market Trading and Liquidity: Theory and Evidence. The Journal of Finance, 62 (5): 2169-2200.

Beny, L. N. (2005). Do Insider Trading Laws Matter? Some Preliminary Comparative Evidence. American Law and Economics Review, 7 (1): 144-183.

Bhattacharya, U. and H. Daouk (2002). The World Price of Insider Trading. The Journal of Finance, 57 (1): 75-108.

Bhattacharya, U. and H. Daouk (2009). When No Law is Better than a Good Law. Review of Finance, 13 (4): 577-627.

Bhushan, R. (1989). Firm Characteristics and Analyst Following. Journal of Accounting and Economics, 11 (2-3): 255-274.

Bris, A., S. Cantale and G. P. Nishiotis (2007). A Breakdown of the Valuation Effects of International Cross-Listing. European Financial Management, 13 (3): 498-530.

Brennan, M. and P. Hughes (1991). Stock Prices and the Supply of Information. The Journal of Finance, 46 (5): 1665-1691.

Brennan, M. J. and H. Cao (1997). International Portfolio Investment Flows. The Journal of Finance, 52 (5): 1851-1880.

Chemmanur, T. J. and P. Fulghieri (2006). Competition and Cooperation among Exchanges: A Theory of Cross-Listing and Endogenous Listing Standards. Journal of Financial Economics, 82 (2): 455-489.

Chiyachantana, C. N., P. K. Jain, C. X. Jiang and R. A. Wood (2004). International Evidence on Institutional Trading Behavior and Price Impact. The Journal of Finance, 59 (2): 869-898.

Chordia, T., S. W. Huh, and A. Subrahmanyam (2007). The Cross-Section of Expected Trading Activity. Review of Financial Studies, 20(3): 709-740.

Chowdhry, B. and V. Nanda (1991). Multimarket Trading and Market Liquidity. Review of Financial Studies, 4 (3): 483-511.

Dahlquist, M., L. Pinkowitz, R. M. Stulz and R. Williamson (2003). Corporate Governance and the Home Bias. Journal of Financial and Quantitative Analysis, 38 (1): 87-110.

Doidge, C., G. A. Karolyi and R. M. Stulz (2004). Why Are Foreign Firms Listed in the U.S. Worth More? Journal of Financial Economics, 71 (2): 205-238.

Doidge, C., G. Andrew Karolyi and R. M. Stulz (2007). Why Do Countries Matter So Much for Corporate Governance? Journal of Financial Economics, 86 (1): 1-39.

Doidge, C., G. A. Karolyi and R. M. Stulz (2009). Has New York Become Less Competitive in Global Markets? Evaluating Foreign Listing Choice over Time. Journal of Financial Economics, 91 (3): 253-277.

Domowitz, I. (2002). Liquidity, Transaction Costs, and Reintermediation in Electronic Markets. Journal of Financial Services Research, 22 (1-2): 141-157.

Durnev, A. A. and A. S. Nain (2007). Does Insider Trading Regulation Deter Private Information Trading? International Evidence. Pacific-Basin Finance Journal, 15 (5): 409-433. 
Fernandes, N. and M. Giannetti (2009). On the Fortunes of Stock Exchanges and Their Reversals: Evidence from Foreign Listings. CEPR Discussion Paper DP7308.

Fisher, P. E. (1992). Optimal Contracting and Insider Trading Restrictions. The Journal of Finance, 47 (2): 673-694.

Fuerst, O. (1998). A Theoretical Analysis of the Investor Protection Regulations Argument for Global Listing of Stocks. Yale School of Management Working paper.

Grinblatt, M. and M. Keloharju (2000). The Investment Behavior and Performance of Various Investor Types: A Study of Finland's Unique Data Set. Journal of Financial Economics, 55 (1): 43-67.

Grinblatt, M. and M. Keloharju (2001). How Distance, Language, and Culture Influence Stockholdings and Trades. The Journal of Finance, 57 (3): 1053-1073.

Halling, M., Pagano, M., Randl, O. and Zechner, J. (2008). Where is the Market? Evidence from Cross-Listings in the US. The Review of Financial Studies, 21 (2): 725-761.

Helflin, F. and K. W. Shaw (2000). Blockholder Ownership and Market Liquidity. Journal of Financial and Quantitative Analysis, 35 (4): 621-633.

Huddart, S., J. S. Hughes and M. K. Brunnermeier (1999). Disclosure Requirements and Stock Exchange Listing Choice in an International Context. Journal of Accounting and Economics, 26 (1-3): 237-269.

Jain, P. K. (2005). Financial Market Design and the Equity Premium: Electronic versus Floor Trading. The Journal of Finance, 60(6): 2955-2985.

Kang, J.-K. and R. M. Stulz (1997). Why is There a Home Bias? An Analysis of Foreign Portfolio Equity Ownership in Japan. Journal of Financial Economics, 46 (1): 3-28.

Krishnamurti, C., A. Sevic and Z. Sevic (2005). Voluntary Disclosure, Transparency, and Market Quality: Evidence from Emerging Market ADRs. Journal of Multinational Financial Management, 15 (4-5): 435-454.

La Porta, R., F. Lopez-de-Silanes, A. Shleifer and R. W. Vishny (2000). Investor Protection and Corporate Governance. Journal of Financial Economics, 58 (1-2): 3-27.

Maug, E. (2002). Insider Trading Legislation and Corporate Governance. European Economic Review, 46 (9): 1569-1597.

Pagano, M. (1989). Trading Volume and Asset Liquidity. Quarterly Journal of Economics, 104 (2): 255-274.

Pagano, M., O. Randl, A. A. Röell, and J. Zechner (2001). What Makes Stock Exchanges Succeed? Evidence from Cross-Listing Decisions. European Economic Review, 45 (4-6): 770-782.

Pagano, M., A. A. Roell, and J. Zechner (2002). The Geography of Equity Listing: Why Do Companies List Abroad? The Journal of Finance, 57 (6): 2651-2694.

Petersen, M. A. (2009). Estimating Standard Errors in Finance Panel Data Sets: Comparing Approaches. Review of Financial Studies, 22 (1): 435-480.

Portes, R. and H. Rey (2005). The Determinants of Cross-border Equity Flows. Journal of International Economics, 65 (2): 269-296.

Pulatkonak, Melek and Sofianos, George (1999). The Distribution of Global Trading in NYSEListed Non-US Stocks. NYSE Working paper 99-03.

Rubin, A. (2007). Ownership Level, Ownership Concentration and Liquidity. Journal of Financial Markets, 10(3): 219-248.

Sabherwal, S. (2007). The U.S. Share of Trading Volume in Cross-Listings: Evidence from Canadian Stocks. The Financial Review, 42 (1): 23-51.

Sarkissian, S. and M. J. Schill (2004). The Overseas Listing Decision: New Evidence of Proximity Preference. Review of Financial Studies, 17 (3): 769-809. 
Sarkissian, S. and M. J. Schill (2009). Are There Permanent Valuation Gains to Overseas Listing? Review of Financial Studies, 22 (1): 371-412.

Serifsoy, B. (2008). Demutualization, Outsider Ownership, and Stock Exchange performance: Empirical Evidence. Economics of Governance, 9 (4): 305-339.

Shleifer, A. and R. W. Vishny (1997). A Survey of Corporate Governance. The Journal of Finance, 52 (2): 737-783.

Venkataraman, K. (2001). Automated versus Floor Trading: An Analysis of Execution Costs on the Paris and New York Exchanges. The Journal of Finance, 56 (4): 1445-1485.

Voth, H.J. (2004). Competition from OTC Cash Equity Trading and the Pricing Behaviour of Stock Exchanges. CEPR.

Welch, I. (2004). Capital Structure and Stock Returns. Journal of Political Economy, 112 (1): 106131.

White, H. (1980). A Heteroskedasticity-Consistent Covariance Matrix Estimator and a Direct Test for Heteroskedasticity. Econometrica, 48 (4): 817-838. 
Figure I. Average stock exchange's share of foreign equity trading

The figures plot the annual average foreign equity trading share and the total annual number of stock-month observations for the pooled sample and individually for eleven major exchanges. The pooled sample includes 795 European cross-listed stocks traded from Jan 1990 to Dec 2007. The average annual foreign trading share is the mean of the stock-level foreign trading shares of all the stocks in the sample that are traded on the stock exchange, calculated monthly as the ratio of the number of shares traded on the exchange to the total number of the shares traded in the same month on all exchanges in the sample.
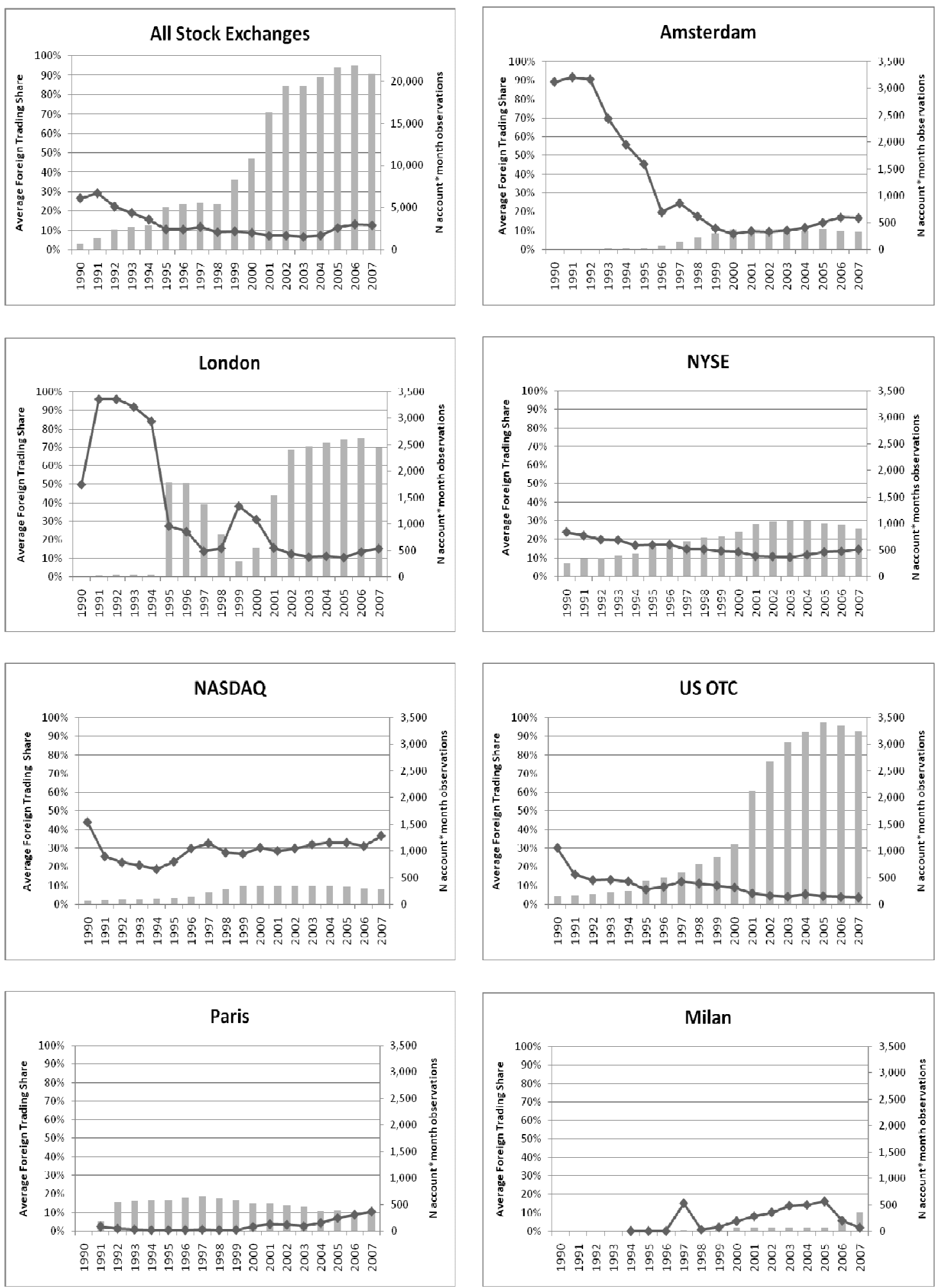
Figure I continued
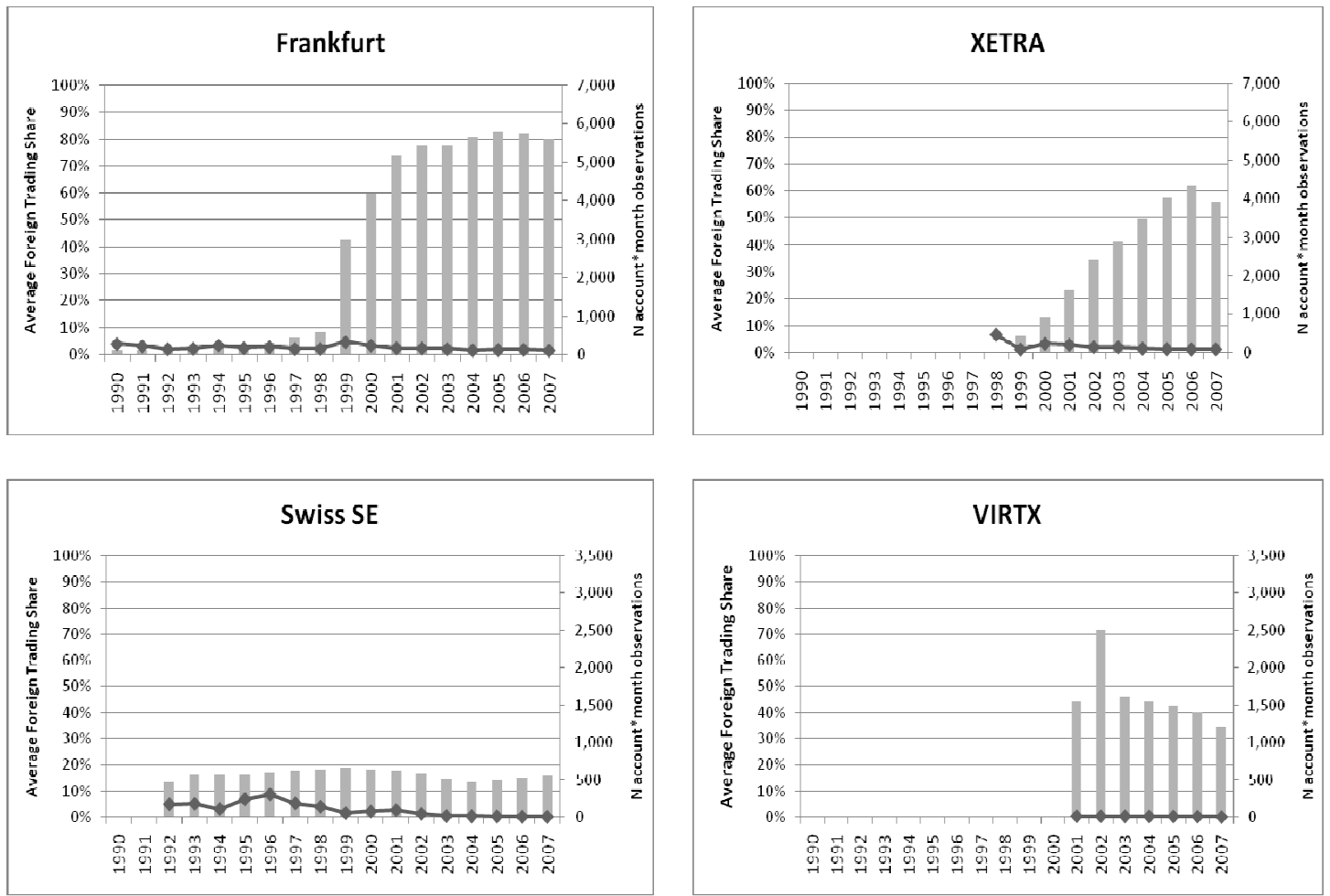
Table I. Potential determinants of the foreign trading volume share

The table presents the list of potential determinants of foreign trading volume share, empirical measures employed to proxy each of the determinants and the sign of the predicted effect of the determinant on foreign trading volume share: '+' positive impact or '-' negative impact.

\begin{tabular}{|c|c|c|}
\hline Determinant & Empirical measure & $\begin{array}{l}\text { Effect on the foreign } \\
\text { trading volume share }\end{array}$ \\
\hline \multicolumn{3}{|c|}{ Host market characteristics - Pull factors } \\
\hline Level of disclosure & Trading platform indicator & - \\
\hline \multirow[t]{2}{*}{ Exchange-specific factors } & Organizational structure - Demutualization indicator & + \\
\hline & Market design - Electronic market indicator & + \\
\hline \multirow[t]{5}{*}{ Trade frictions } & Common language & + \\
\hline & Geographic distance & - \\
\hline & Market size & + \\
\hline & Aggregate market liquidity & + \\
\hline & Trading costs & - \\
\hline \multirow[t]{2}{*}{ Legal environment } & Investor protection & + \\
\hline & Insider trading laws enforced & + \\
\hline Information environment & Accounting opacity & - \\
\hline \multicolumn{3}{|l|}{ Stock-level factors } \\
\hline \multicolumn{3}{|l|}{ Listing characteristics } \\
\hline Level of disclosure & Traded (vs. exchange-listed) & - \\
\hline \multirow[t]{3}{*}{ Stock visibility } & First foreign listing & + \\
\hline & Time listed & + \\
\hline & Price level & + \\
\hline \multirow[t]{2}{*}{ Trade frictions } & The same currency of listing & + \\
\hline & DR (vs. ordinary listing) & - \\
\hline \multicolumn{3}{|l|}{ Company characteristics } \\
\hline \multirow[t]{3}{*}{ Company visibility } & Company size & - \\
\hline & Company growth opportunities & + \\
\hline & Company foreign sales & + \\
\hline \multirow[t]{2}{*}{ Ownership structure } & Company's foreign institutional ownership & + \\
\hline & Ownership concentration & - \\
\hline Stock risk & Stock return variance & + \\
\hline Level of transparency & International accounting standards used & + \\
\hline Returns co-movement & Stock retrun correrlation with foreign market & - \\
\hline with foreign market & Foreign information factor & + \\
\hline \multicolumn{3}{|c|}{ Home market characteristics } \\
\hline Economic development & Level of development & + \\
\hline \multirow[t]{2}{*}{ Legal environment } & Investor protection & - \\
\hline & Insider trading laws enforced & - \\
\hline Information environment & Accounting opacity & - \\
\hline Trade frictions & Trading costs & + \\
\hline
\end{tabular}


Table II. Average foreign trading volume share and Pull factors: Summary statistics

The table reports summary statistics of the average foreign trading volume share and host exchangespecific factors, the pull factors of the foreign equity trading, for the pooled sample that contains 39 stock exchanges and individually for 11 major stock exchanges. The sample includes 795 European cross-listed stocks traded from Jan 1990 to Dec 2007. The average foreign trading volume share is the mean of the foreign trading volume shares of the stocks traded on the exchange in each month. The pull factors are defined in Appendix A.

\begin{tabular}{|c|c|c|c|c|c|c|c|c|c|c|c|c|}
\hline & 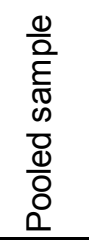 & 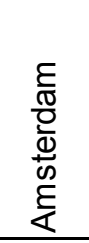 & 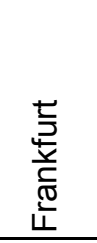 & $\begin{array}{l}\text { 음 } \\
\text { రํ. }\end{array}$ & 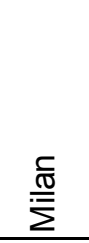 & 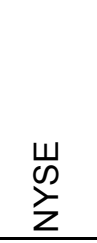 & $\begin{array}{l}\sigma \\
\mathbb{0} \\
0 \\
\mathbb{0} \\
\mathbb{Z} \\
\end{array}$ & $\stackrel{0}{\circ}$ & $\begin{array}{l}\mathscr{\infty} \\
\bar{\sigma} \\
\Delta\end{array}$ & $\begin{array}{l}山 \\
\omega \\
\infty \\
\infty \\
\sum \\
\text { क }\end{array}$ & 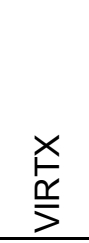 & $\begin{array}{l}\underset{\underline{r}}{\underline{w}} \\
\underset{x}{\underline{x}} \\
\end{array}$ \\
\hline \multicolumn{13}{|c|}{ Panel A. Average foreign trading volume share } \\
\hline Average foreign trading share & 0.119 & 0.349 & 0.025 & 0.366 & 0.069 & 0.155 & 0.292 & 0.097 & 0.029 & 0.029 & 0.002 & 0.02 \\
\hline AFTVS by year: 1996 & 0.103 & 0.198 & 0.027 & 0.244 & 0.000 & 0.172 & 0.299 & 0.093 & 0.005 & 0.088 & & \\
\hline 1997 & 0.117 & 0.246 & 0.020 & 0.139 & 0.151 & 0.147 & 0.327 & 0.120 & 0.006 & 0.053 & & \\
\hline 1998 & 0.090 & 0.176 & 0.020 & 0.155 & 0.008 & 0.146 & 0.276 & 0.111 & 0.005 & 0.040 & & 0.067 \\
\hline 1999 & 0.094 & 0.112 & 0.046 & 0.382 & 0.020 & 0.137 & 0.270 & 0.099 & 0.005 & 0.015 & & 0.011 \\
\hline 2000 & 0.087 & 0.083 & 0.033 & 0.310 & 0.054 & 0.132 & 0.303 & 0.089 & 0.022 & 0.021 & & 0.032 \\
\hline 2001 & 0.071 & 0.098 & 0.023 & 0.157 & 0.080 & 0.109 & 0.285 & 0.058 & 0.036 & 0.027 & 0.003 & 0.028 \\
\hline 2002 & 0.072 & 0.095 & 0.023 & 0.124 & 0.102 & 0.108 & 0.299 & 0.046 & 0.032 & 0.013 & 0.003 & 0.020 \\
\hline 2003 & 0.065 & 0.101 & 0.020 & 0.107 & 0.138 & 0.104 & 0.320 & 0.040 & 0.024 & 0.004 & 0.003 & 0.020 \\
\hline 2004 & 0.073 & 0.116 & 0.015 & 0.112 & 0.142 & 0.117 & 0.330 & 0.053 & 0.042 & 0.003 & 0.002 & 0.014 \\
\hline 2005 & 0.112 & 0.142 & 0.017 & 0.105 & 0.161 & 0.132 & 0.330 & 0.043 & 0.069 & 0.002 & 0.002 & 0.012 \\
\hline 2006 & 0.130 & 0.170 & 0.017 & 0.135 & 0.057 & 0.135 & 0.311 & 0.039 & 0.087 & 0.001 & 0.002 & 0.011 \\
\hline 2007 & 0.125 & 0.167 & 0.014 & 0.153 & 0.019 & 0.146 & 0.367 & 0.036 & 0.103 & 0.001 & 0.000 & 0.012 \\
\hline $\mathrm{N}$ observations, $\%$ of total & & $1.8 \%$ & $19.2 \%$ & $11.4 \%$ & $0.6 \%$ & $11.2 \%$ & $3.4 \%$ & $12.5 \%$ & $8.9 \%$ & $8.7 \%$ & $8.2 \%$ & $12.4 \%$ \\
\hline \multicolumn{13}{|c|}{ Panel B. Pull factors of foreign equity trading } \\
\hline Trading platform indicator & 0.11 & 0 & 0 & 0 & 0 & 0 & 0 & 1 & 0 & 0 & 1 & 1 \\
\hline Demutualization indicator & 0.52 & 0.62 & 0.44 & 0.45 & 0.70 & 0.11 & 0.44 & & 0.48 & 0.38 & 0.91 & 0.86 \\
\hline Electronic market indicator & 0.84 & 0.79 & 0.94 & 0.63 & 0.89 & 0.44 & 1.00 & 0.44 & 1.00 & 0.76 & 1.00 & 1.00 \\
\hline Foreign stock concentration & 0.23 & 0.42 & 0.20 & 0.12 & 0.02 & 0.19 & 0.10 & & 0.15 & 0.35 & & \\
\hline Market size, billion GBP & 1299 & 262 & 463 & 1113 & 285 & 5157 & 5157 & 5157 & 560 & 337 & 461 & 643 \\
\hline Market liquidity & 66.1 & 84.5 & 93.1 & 75.5 & 79.0 & 100.0 & 100.0 & 100.0 & 60.0 & 57.7 & 66.6 & 37.0 \\
\hline Trading costs & 0.62 & 0.47 & 0.57 & 0.56 & 0.45 & 0.64 & 0.64 & 0.64 & 0.50 & 0.94 & 0.94 & 0.57 \\
\hline Investor protection & 0.46 & 0.20 & 0.28 & 0.95 & 0.42 & 0.65 & 0.65 & 0.65 & 0.38 & 0.27 & 0.27 & 0.28 \\
\hline IT laws enforcement & 0.80 & 0.79 & 0.72 & 1.00 & 0.76 & 1.00 & 1.00 & 1.00 & 1.00 & 0.82 & 1.00 & 1.00 \\
\hline Accounting opacity & 0.30 & 0.38 & 0.17 & 0.33 & 0.63 & 0.20 & 0.20 & 0.20 & 0.33 & 0.25 & 0.25 & 0.17 \\
\hline \multicolumn{13}{|l|}{ Average company size, } \\
\hline million GBP & 11.39 & 13.45 & 8.99 & 6.16 & 15.49 & 15.54 & 3.11 & 5.09 & 15.97 & 13.14 & 18.56 & 16.07 \\
\hline
\end{tabular}


Table III. Stock-level variables: Summary statistics

Table reports summary statistics of stock-level determinants of the foreign trading volume share for the pooled sample, for individual sub-samples of eleven major stock exchanges and for sub-samples of listed and traded foreign accounts. The sample includes 599 European cross-listed stocks traded from Jan 2003 to Dec 2007. The determinants are defined in Appendix A.

\begin{tabular}{|c|c|c|c|c|c|c|c|c|c|c|c|c|c|c|c|c|c|}
\hline & \multirow{2}{*}{\multicolumn{4}{|c|}{ Poooled sample }} & \multicolumn{11}{|c|}{ By stock exchange } & \multirow{2}{*}{\multicolumn{2}{|c|}{$\begin{array}{l}\text { Listed vs. } \\
\text { traded }\end{array}$}} \\
\hline & & & & & \multirow{2}{*}{ 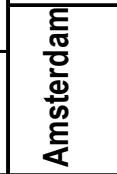 } & \multirow{2}{*}{ 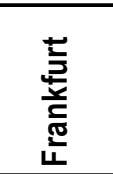 } & \multirow[b]{2}{*}{$\begin{array}{l}\text { 흐 } \\
\text { 임 }\end{array}$} & \multirow[b]{2}{*}{$\frac{\stackrel{c}{\frac{\sigma}{\tilde{J}}}}{\bar{\Sigma}}$} & \multirow[b]{2}{*}{ 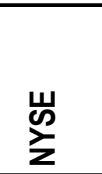 } & \multirow[b]{2}{*}{$\begin{array}{l}\bar{\sigma} \\
\text { J } \\
\text { D } \\
\text { Z }\end{array}$} & \multirow[b]{2}{*}{ 능 } & \multirow[b]{2}{*}{$\frac{\text { on }}{\pi}$} & \multirow[b]{2}{*}{$\begin{array}{l}\text { 岕 } \\
\text { 岕 } \\
\text { के }\end{array}$} & \multirow[b]{2}{*}{$\begin{array}{l}\stackrel{x}{k} \\
\stackrel{\underline{\alpha}}{>}\end{array}$} & \multirow[b]{2}{*}{ 羊 } & & \\
\hline & Mean & $\mathbf{N}$ & Min & Max & & & & & & & & & & & & $\begin{array}{l}\text { Listed } \\
\text { Mean }\end{array}$ & $\begin{array}{c}\text { Traded } \\
\text { Mean }\end{array}$ \\
\hline \multicolumn{18}{|l|}{ Listing characteristics } \\
\hline Traded indicator & 0.71 & 51,846 & 0 & 1 & 0 & 0.88 & 0.65 & 1 & 0 & 0 & 1 & 0 & 0 & 1 & 0.82 & 0 & 1 \\
\hline First listing & 0.02 & 51,846 & 0 & 1 & 0.02 & 0 & 0.12 & 0 & 0 & 0.09 & 0 & 0 & 0 & 0 & 0 & 0.07 & 0 \\
\hline Time listed & 6.24 & 51,846 & 0.17 & 22 & 5.92 & 6.24 & 4.64 & 4.35 & 10.61 & 10.19 & 6.26 & 9.66 & 12.72 & 5.86 & 4.38 & 8.26 & 5.42 \\
\hline Price level & 19.9 & 51,846 & 0.01 & 5841 & 20.7 & 22.4 & 19.5 & 25.0 & 18.8 & 10.6 & 15.5 & 22.9 & 33.2 & 30.7 & 18.8 & 18.15 & 20.66 \\
\hline Same currency & 0.4 & 51,846 & 0 & 1 & 0.80 & 0.55 & 0.27 & 0.98 & 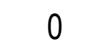 & 0 & 0 & 0.67 & 0 & 1 & 0.57 & 0.43 & 0.39 \\
\hline DR indicator & 0.27 & 51,846 & 0 & 1 & 0 & 0.11 & 0.03 & 0 & 0.95 & 0.89 & 0.75 & 0 & 0 & 0 & 0.10 & 0.29 & 0.26 \\
\hline \multicolumn{18}{|c|}{ Company characteristics } \\
\hline Company size, mln GBP & $\mid 15,254$ & 51,846 & 1.55 & 127,867 & 25,346 & 12,831 & 14,275 & 30,891 & 23,385 & 3,851 & 9,589 & 23,886 & 23,435 & 526,850 & 18,836 & 18,221 & 14,039 \\
\hline Price-to-book ratio & 3.07 & 51,846 & 0.02 & 194.68 & 2.72 & 3.26 & 2.78 & 2.00 & 4.83 & 3.21 & 2.70 & 2.18 & 2.66 & 2.87 & 3.07 & 3.06 & 3.07 \\
\hline Foreign sales fractio & 0.57 & 51,846 & 0 & 1 & 0.59 & 0.57 & 0.56 & 0.57 & 0.57 & 0.68 & 0.54 & 0.56 & 0.65 & 0.59 & 0.57 & 0.59 & 0.56 \\
\hline Foreign investors & 0.08 & 51,846 & 0 & 0.94 & 0.03 & 0.08 & 0.09 & 0.03 & 0.08 & 0.09 & 0.08 & 0.08 & 0.05 & 0.05 & 0.07 & 0.07 & 0.08 \\
\hline Ownership concentration & 0.26 & 51,846 & 0 & 0.96 & 0.19 & 0.30 & 0.25 & 0.11 & 0.25 & 0.28 & 0.29 & 0.24 & 0.19 & 0.17 & 0.24 & 0.23 & 0.27 \\
\hline Stock risk & 0.04 & 51,846 & 0 & 0.45 & 0.04 & 0.04 & 0.04 & 0.04 & 0.04 & 0.06 & 0.04 & 0.04 & 0.03 & 0.03 & 0.04 & 0.04 & 0.04 \\
\hline Int. accounting standards & 0.73 & 51,846 & 0 & 1 & 0.78 & 0.70 & 0.72 & 0.90 & 0.70 & 0.68 & 0.70 & 0.74 & 1 & 1 & 0.75 & 0.71 & 0.74 \\
\hline Return correlation & 0.48 & 51,846 & -0.15 & 0.94 & 0.59 & 0.48 & 0.49 & 0.65 & 0.46 & 0.35 & 0.40 & 0.60 & 0.52 & 0.52 & 0.53 & 0.49 & 0.48 \\
\hline Foreign information factor & 2.62 & 51,846 & 0 & 27.67 & 3.64 & 2.89 & 1.93 & 1.84 & 2.65 & 3.02 & 1.98 & 2.69 & 1.94 & 1.47 & 3.23 & 2.75 & 2.56 \\
\hline \multicolumn{18}{|c|}{ Home market characteristics } \\
\hline Emerging market indicator & 0.02 & 51,846 & 0 & 1 & 0 & 0.04 & 0.01 & 0 & 0.01 & 0 & 0.01 & 0 & 0 & 0 & 0.03 & 0 & 0.03 \\
\hline
\end{tabular}


Table III continued

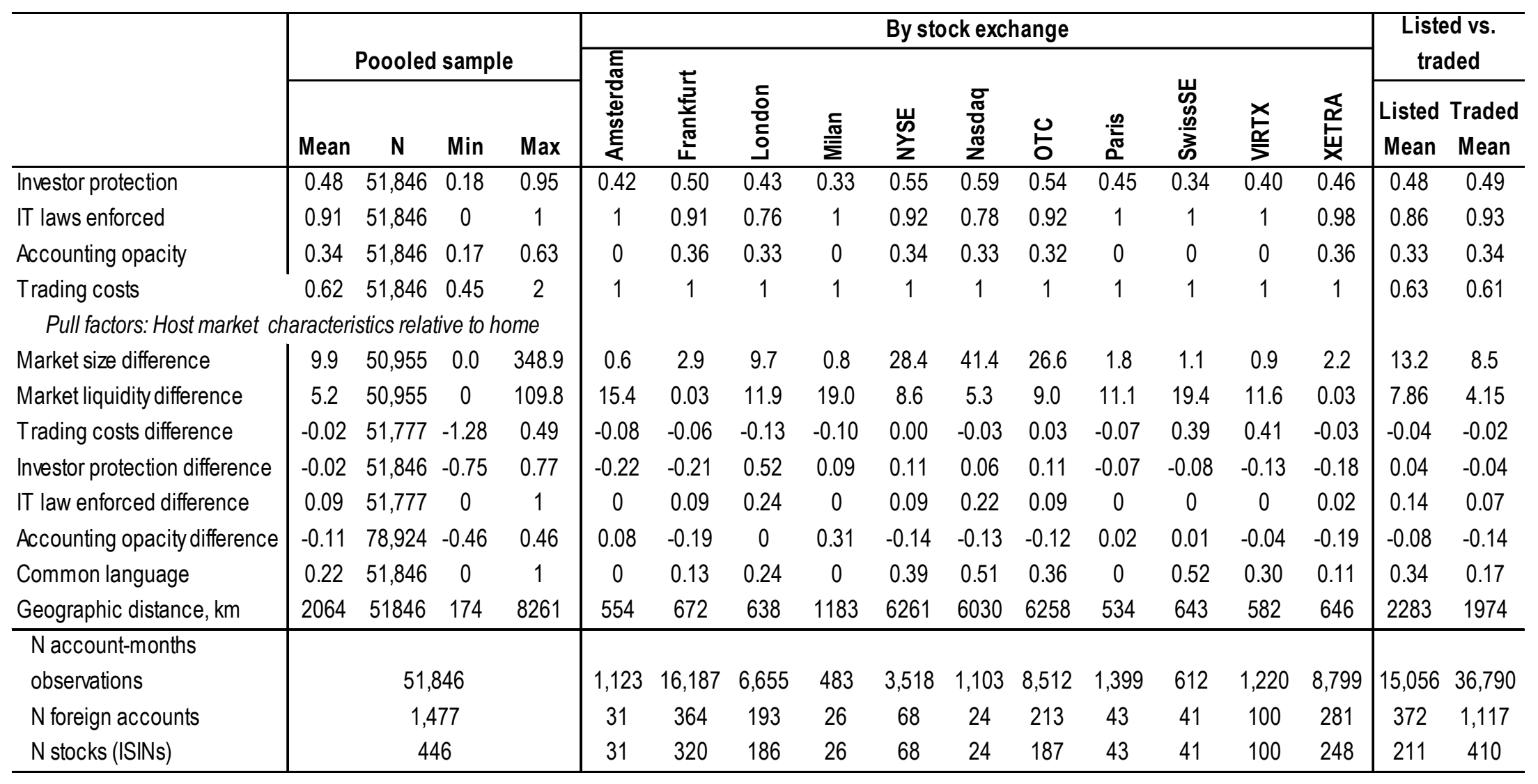


Table IV. Pull factors: Correlation matrix

The table reports the correlation matrix of the average foreign trading volume share and the host exchange characteristics, the pull factors of the foreign equity trading. The sample includes 795 European cross-listed stocks traded from Jan 1990 to Dec 2007. Average foreign trading volume shares is the mean of the foreign trading volume shares of the stocks traded on the exchange in each month. The pull factors are defined in Appendix A.

\begin{tabular}{|c|c|c|c|c|c|c|c|c|c|c|c|}
\hline & 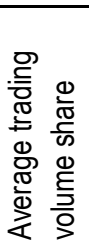 & 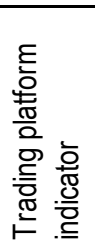 & 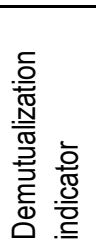 & 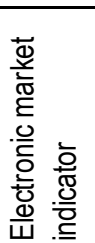 & 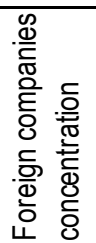 & 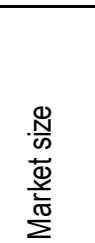 & 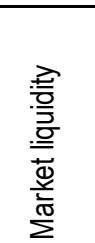 & 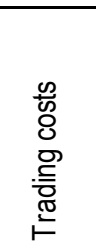 & 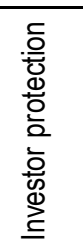 & 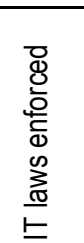 & 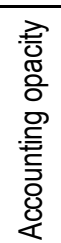 \\
\hline Trading platform indicator & $\begin{array}{c}-0.05 \\
(0)\end{array}$ & 1 & & & & & & & & & \\
\hline Demutualization indicator & $\begin{array}{c}-0.08 \\
(0)\end{array}$ & $\begin{array}{l}0.2 \\
(0)\end{array}$ & 1 & & & & & & & & \\
\hline Electronic market indicator & $\begin{array}{c}-0.31 \\
(0)\end{array}$ & $\begin{array}{c}-0.14 \\
(0)\end{array}$ & $\begin{array}{l}0.43 \\
(0)\end{array}$ & 1 & & & & & & & \\
\hline $\begin{array}{l}\text { Foreign companies } \\
\text { concentration }\end{array}$ & $\begin{array}{l}-0.56 \\
(0)\end{array}$ & $\begin{array}{l}- \\
-\end{array}$ & $\begin{array}{l}-0.1 \\
(0)\end{array}$ & $\begin{array}{c}0.04 \\
(0.16)\end{array}$ & 1 & & & & & & \\
\hline Market size & $\begin{array}{c}0.33 \\
(0)\end{array}$ & $\begin{array}{l}0.34 \\
(0)\end{array}$ & $\begin{array}{c}0.04 \\
(0.04)\end{array}$ & $\begin{array}{c}-0.12 \\
(0)\end{array}$ & $\begin{array}{c}-0.35 \\
(0)\end{array}$ & 1 & & & & & \\
\hline Market liquidity & $\begin{array}{c}0.39 \\
(0)\end{array}$ & $\begin{array}{c}0 \\
(0.88)\end{array}$ & $\begin{array}{l}-0.03 \\
(0.16)\end{array}$ & $\begin{array}{c}-0 \\
(0.98)\end{array}$ & $\begin{array}{c}-0.62 \\
(0)\end{array}$ & $\begin{array}{c}0.45 \\
(0)\end{array}$ & 1 & & & & \\
\hline Trading costs & $\begin{array}{c}-0.26 \\
(0)\end{array}$ & $\begin{array}{l}0.14 \\
(0)\end{array}$ & $\begin{array}{l}0.09 \\
(0)\end{array}$ & $\begin{array}{c}0.02 \\
(0.26)\end{array}$ & $\begin{array}{c}0.11 \\
(0)\end{array}$ & $\begin{array}{c}-0.11 \\
(0)\end{array}$ & $\begin{array}{c}0.05 \\
(0.01)\end{array}$ & 1 & & & \\
\hline Investor protection & $\begin{array}{c}0.47 \\
(0)\end{array}$ & $\begin{array}{l}0.03 \\
(0.13)\end{array}$ & $\begin{array}{l}-0.2 \\
(0)\end{array}$ & $\begin{array}{l}-0.27 \\
(0)\end{array}$ & $\begin{array}{l}-0.35 \\
(0)\end{array}$ & $\begin{array}{l}0.42 \\
(0)\end{array}$ & $\begin{array}{l}0.27 \\
(0)\end{array}$ & $\begin{array}{l}-0.03 \\
(0.09)\end{array}$ & 1 & & \\
\hline IT laws enforced & $\begin{array}{l}0.23 \\
(0)\end{array}$ & $\begin{array}{l}0.19 \\
(0)\end{array}$ & $\begin{array}{l}0.29 \\
(0)\end{array}$ & $\begin{array}{l}0.1 \\
(0)\end{array}$ & $\begin{array}{c}0.02 \\
(0.49)\end{array}$ & $\begin{array}{l}0.56 \\
(0)\end{array}$ & $\begin{array}{l}0.11 \\
(0)\end{array}$ & $\begin{array}{l}-0.25 \\
(0)\end{array}$ & $\begin{array}{l}0.14 \\
(0)\end{array}$ & 1 & \\
\hline Accounting opacity & $\begin{array}{c}-0.06 \\
(0)\end{array}$ & $\begin{array}{c}-0.32 \\
(0)\end{array}$ & $\begin{array}{l}0.13 \\
(0)\end{array}$ & $\begin{array}{c}0.19 \\
(0)\end{array}$ & $\begin{array}{c}-0.31 \\
(0)\end{array}$ & $\begin{array}{c}-0.43 \\
(0)\end{array}$ & $\begin{array}{c}0.17 \\
(0)\end{array}$ & $\begin{array}{c}-0.27 \\
(0)\end{array}$ & $\begin{array}{c}-0.07 \\
(0)\end{array}$ & $\begin{array}{c}-0.21 \\
(0)\end{array}$ & 1 \\
\hline Average company size & $\begin{array}{l}-0.2 \\
(0)\end{array}$ & $\begin{array}{l}0.03 \\
(0.12)\end{array}$ & $\begin{array}{l}0.35 \\
(0)\end{array}$ & $\begin{array}{l}0.3 \\
(0)\end{array}$ & $\begin{array}{l}0.18 \\
(0)\end{array}$ & $\begin{array}{l}-0.03 \\
(0.13)\end{array}$ & $\begin{array}{l}-0.01 \\
(0.52)\end{array}$ & $\begin{array}{l}-0.03 \\
(0.09)\end{array}$ & $\begin{array}{l}-0.31 \\
(0)\end{array}$ & $\begin{array}{l}0.2 \\
(0)\end{array}$ & $\begin{array}{l}0.13 \\
(0)\end{array}$ \\
\hline
\end{tabular}


Table V. Pull factors of the foreign equity trading

The table reports the estimates from the OLS regressions of the dependant variable, the logistic transformation of stock exchange's monthly average foreign share of trading volume. The sample includes 795 European cross-listed stocks traded from Jan 1990 to Dec 2007. The exchange-level average foreign trading share is the mean of the foreign trading volume shares of the stocks traded on the exchange, calculated monthly as the ratio of the number of shares traded on the exchange to the total number of the shares traded in the same month on all exchanges in the sample. Regression specification is as follows: $\log \operatorname{tr} A F T V S_{n}=\alpha_{0}+\sum \theta_{k} Z_{k, n}+C_{n}+\varepsilon_{n}$, where $\log \operatorname{trAFTVS} S_{n}=\ln \left(\operatorname{AFTVS}_{n} /\left(1-A F T V S_{n}\right)\right.$; $A F T V S_{n}$ is average foreign trading volumes share of host exchange $n$ in month $t ; Z_{k, n}$ is characteristic $k$ of host market $n$ in month $t$, and $C_{n}$ is average size of companies traded on host exchange $n$ in month $t$ (control variable). The explanatory variables are defined in Appendix A. Additionally, regressions include a control variable, average company size measured by the natural logarithm of the mean stock market value of stocks traded on the exchange converted to GBP. Output for model (2) additionally includes economic significance (econ. sign.) of the variables calculated as the product of the coefficient estimate and the variable's standard deviation divided by the standard deviation of the dependent variable. Reported in parenthesis t-value is heteroskedasticity consistent (White, 1980) and adjusted for clustering at the stock exchange level. ' $* * *$ ' indicates significance at $1 \%$, ' $* *$ ' indicates significance at $5 \%$ and '*' indicates significance at $10 \%$.

\begin{tabular}{|c|c|c|c|c|c|}
\hline & \multirow[b]{2}{*}{ Model (1) } & \multicolumn{2}{|c|}{ Model (2) } & \multirow[t]{2}{*}{ Model (3) } & \multirow[t]{2}{*}{ Model (4) } \\
\hline & & \multicolumn{2}{|c|}{ Econ. sign. } & & \\
\hline \multirow[t]{2}{*}{ Intercept } & 3.51 & $6.83^{*}$ & & $12.27^{\star * *}$ & 3.23 \\
\hline & (1.73) & $(1.84)$ & & (3.35) & $(0.8)$ \\
\hline \multirow[t]{2}{*}{ Trading platform } & $-1.13^{*}$ & $-1.20^{*}$ & -0.14 & -1.08 & \\
\hline & $(-1.87)$ & $(-1.79)$ & & $(-1.69)$ & \\
\hline \multirow[t]{2}{*}{ Demutualization } & $1.17^{* *}$ & $1.13^{*}$ & 0.25 & -0.20 & \\
\hline & (2.39) & $(1.9)$ & & $(-0.47)$ & \\
\hline \multirow[t]{2}{*}{ Electronic market } & $-1.89^{* * *}$ & $-2.36^{* *}$ & -0.35 & $-2.76^{* * *}$ & $-1.58^{* *}$ \\
\hline & $(-3.34)$ & $(-2.89)$ & & $(-4.32)$ & $(-2.8)$ \\
\hline \multirow[t]{2}{*}{ Market size } & $0.42^{* * *}$ & 0.10 & & -0.09 & 0.09 \\
\hline & (3.92) & $(0.69)$ & & $(-0.85)$ & $(0.47)$ \\
\hline \multirow[t]{2}{*}{ Market liquidity } & $0.29^{*}$ & $0.46^{* * *}$ & 0.21 & $0.52^{* * *}$ & $0.50^{* *}$ \\
\hline & (2.09) & (3.11) & & (3.66) & (2.2) \\
\hline \multirow[t]{2}{*}{ Trading costs } & $-4.14^{* * *}$ & $-4.35^{* *}$ & -0.29 & $-5.00^{* * *}$ & -2.39 \\
\hline & $(-3.36)$ & $(-2.6)$ & & $(-3.21)$ & $(-1.2)$ \\
\hline \multirow[t]{2}{*}{ Investor protection } & & 0.31 & & 0.01 & 0.88 \\
\hline & & $(0.2)$ & & $(0.01)$ & $(0.52)$ \\
\hline \multirow{2}{*}{ IT laws enforced } & & $1.44^{* *}$ & 0.24 & $1.65^{\star * *}$ & $1.55^{\star *}$ \\
\hline & & $(2.77)$ & & $(3.51)$ & (2.34) \\
\hline \multirow[t]{2}{*}{ Accounting opacity } & & $-3.57^{*}$ & -0.21 & $-3.62^{* *}$ & -1.84 \\
\hline & & $(-1.97)$ & & $(-2.33)$ & $(-1)$ \\
\hline \multirow[t]{2}{*}{ Average company size } & $-1.02^{\star \star *}$ & $-0.98^{* * *}$ & -0.42 & $-1.32^{\star \star *}$ & $-0.83^{* * *}$ \\
\hline & $(-8.66)$ & $(-4.7)$ & & $(-5.81)$ & $\begin{array}{c}(-4.05) \\
-1.90^{\star \star \star}\end{array}$ \\
\hline OTC indicator & & & & & $\begin{array}{c}(-4.99) \\
-2.26^{* * *}\end{array}$ \\
\hline VIRTX indicator & & & & & $\begin{array}{c}(-4.26) \\
0.35\end{array}$ \\
\hline XETRA indicator & & & & & $(0.79)$ \\
\hline Year-fixed effects & No & No & & Yes & No \\
\hline Exchange-fixed effects & No & No & & No & Yes \\
\hline Number of exchanges & 16 & 13 & & 13 & 15 \\
\hline Number of observations & 2,574 & 2,237 & & 2,237 & 2,572 \\
\hline Adj. R-sq & 0.538 & 0.616 & & 0.666 & 0.564 \\
\hline
\end{tabular}


Table VI. Stock - level determinants of the foreign trading volume share by stock exchange

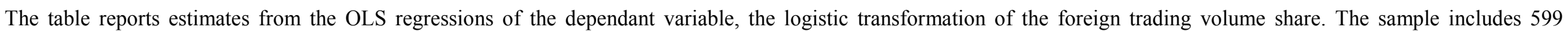

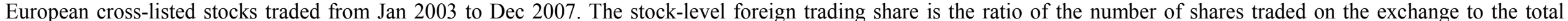

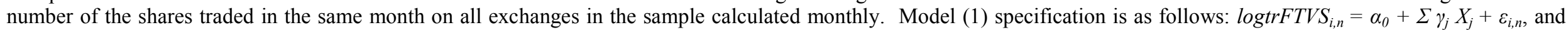

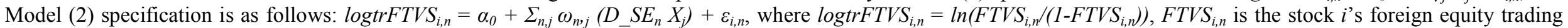
volume share on the exchange $n$ in month $t ; X_{j}$ is vector of stock-level factors; $D S E_{n}$ is dummy variable that equals one if trading takes place on exchange $n$ and zero otherwise.

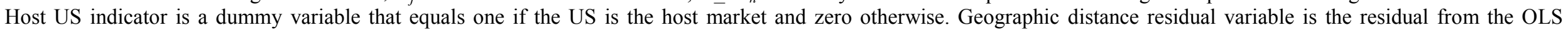
regression of the geographic distance variable on the US host market dummy variable. Other explanatory variables are defined in Appendix A. Reported in parenthesis t-value is heteroskedasticity consistent (White, 1980) and adjusted for clustering at the foreign account level. ' $* * *$ ' indicates significance at $1 \%$, ' $* *$ ' indicates significance at $5 \%$ and ' $*$ ' indicates significance at $10 \%$.

\begin{tabular}{|c|c|c|c|c|c|c|c|c|c|c|c|c|}
\hline & \multirow{2}{*}{$\begin{array}{l}\text { Model (1) } \\
\text { 엉 } \frac{\Phi}{\circ} \\
\frac{\Phi}{\circ} \text { ह } \\
\therefore\end{array}$} & \multicolumn{11}{|c|}{ Model (2) } \\
\hline & & 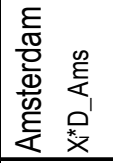 & 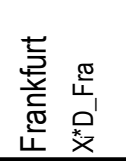 & 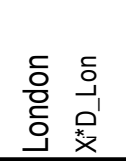 & 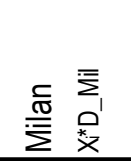 & 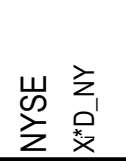 & 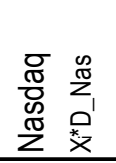 & 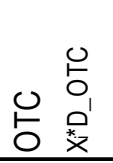 & 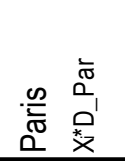 & 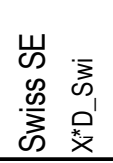 & 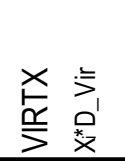 & 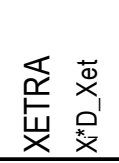 \\
\hline Listing charactersitics & & & & & & & & & & & & \\
\hline Traded indicator & $\begin{array}{c}-1.68^{* * *} \\
(-9.26)\end{array}$ & & $\begin{array}{c}-1.06^{* * *} \\
(-3.54)\end{array}$ & $\begin{array}{l}-0.29 \\
(-0.68)\end{array}$ & & & & & & & & $\begin{array}{l}-0.79^{* *} \\
(-2.08)\end{array}$ \\
\hline First listing & $\begin{array}{c}2.28^{* * *} \\
(5.18)\end{array}$ & $\begin{array}{l}-1.24^{*} \\
(-1.94)\end{array}$ & $\begin{array}{l}0.0 \\
(0.0)\end{array}$ & $\begin{array}{l}-0.62 \\
(-1.09)\end{array}$ & & $\begin{array}{c}-2.73^{* * *} \\
(-3.45)\end{array}$ & $\begin{array}{l}0.65 \\
(0.73)\end{array}$ & & $\begin{array}{c}-3.89 * * * \\
(-3.52)\end{array}$ & & & \\
\hline Time listed/ traded & $\begin{array}{c}0.14^{* * *} \\
(7.96)\end{array}$ & $\begin{array}{c}-0.16 \\
(-1.64)\end{array}$ & $\begin{array}{c}0.13^{* * *} \\
(4.59)\end{array}$ & $\begin{array}{l}0.13 \\
(1.49)\end{array}$ & $\begin{array}{l}0.09 \\
(0.63)\end{array}$ & $\begin{array}{l}0.06^{* *} \\
(2.30)\end{array}$ & $\begin{array}{c}-0.1 \\
(-1.61)\end{array}$ & $\begin{array}{l}0.05^{*} \\
(1.70)\end{array}$ & $\begin{array}{l}-0.17^{* *} \\
(-2.05)\end{array}$ & $\begin{array}{l}0.01 \\
(0.23)\end{array}$ & $\begin{array}{l}-1.17^{* * *} \\
(-10.39)\end{array}$ & $\begin{array}{c}0.49^{* * *} \\
(9.15)\end{array}$ \\
\hline Same currency & $\begin{array}{c}1.15^{\star * *} \\
(6.13)\end{array}$ & $\begin{array}{c}0.44 \\
(0.37)\end{array}$ & $\begin{array}{c}0.80^{* *} \\
(2.53)\end{array}$ & $\begin{array}{l}1.91^{* *} \\
(2.30)\end{array}$ & $\begin{array}{c}-15.43^{* *} \\
(-2.21)\end{array}$ & & & & $\begin{array}{l}0.37 \\
(0.45)\end{array}$ & & & $\begin{array}{c}1.55^{\star * *} \\
(2.98)\end{array}$ \\
\hline DR indicator & $\begin{array}{l}-0.53^{* *} \\
(-2.14)\end{array}$ & & $\begin{array}{c}-2.25^{\star * *} \\
(-8.34)\end{array}$ & $\begin{array}{c}-3.63^{* * *} \\
(-2.63)\end{array}$ & & $\begin{array}{c}0.01 \\
(0.02)\end{array}$ & $\begin{array}{l}-1.48 \\
(-1.41)\end{array}$ & $\begin{array}{c}1.98^{* * *} \\
(5.01)\end{array}$ & & & & $\begin{array}{c}-3.01^{* * *} \\
(-8.98)\end{array}$ \\
\hline $\begin{array}{l}\text { Price level } \\
\text { Company charactersitics }\end{array}$ & $\begin{array}{l}0.08 \\
(1.03)\end{array}$ & $\begin{array}{c}0.37 \\
(1.29)\end{array}$ & $\begin{array}{c}0.25^{\star *} \\
(2.37)\end{array}$ & $\begin{array}{c}0.15 \\
(1.05)\end{array}$ & $\begin{array}{l}-0.25 \\
(-0.56)\end{array}$ & $\begin{array}{l}0.26^{*} \\
(1.81)\end{array}$ & $\begin{array}{l}-0.34 \\
(-0.94)\end{array}$ & $\begin{array}{c}0.44^{* * *} \\
(2.63)\end{array}$ & $\begin{array}{c}-0.90 * * * \\
(-3.14)\end{array}$ & $\begin{array}{l}0.09 \\
(0.42)\end{array}$ & $\begin{array}{l}-0.03 \\
(-0.14)\end{array}$ & $\begin{array}{l}-0.11 \\
(-0.68)\end{array}$ \\
\hline Company size & $\begin{array}{c}-0.27^{* * *} \\
(-5.24)\end{array}$ & $\begin{array}{c}-1.28^{* * *} \\
(-4.18)\end{array}$ & $\begin{array}{c}-0.1 \\
(-1.39)\end{array}$ & $\begin{array}{l}-0.22 \\
(-1.41)\end{array}$ & $\begin{array}{l}-2.12^{* *} \\
(-2.10)\end{array}$ & $\begin{array}{c}0.11 \\
(0.69)\end{array}$ & $\begin{array}{l}0.11 \\
(0.37)\end{array}$ & $\begin{array}{l}-0.25^{\star *} \\
(-2.48)\end{array}$ & $\begin{array}{c}0.17 \\
(0.67)\end{array}$ & $\begin{array}{l}-0.07 \\
(-0.43)\end{array}$ & $\begin{array}{c}0.45^{\star * *} \\
(3.98)\end{array}$ & $\begin{array}{l}0.22^{* *} \\
(2.03)\end{array}$ \\
\hline Price-to-book ratio & $\begin{array}{l}-0.003 \\
(-0.56)\end{array}$ & $\begin{array}{l}0.17^{* *} \\
(2.41)\end{array}$ & $\begin{array}{c}-0.01^{* * *} \\
(-3.91)\end{array}$ & $\begin{array}{l}-0.1^{* *} \\
(-2.50)\end{array}$ & $\begin{array}{l}1.04^{* *} \\
(2.03)\end{array}$ & $\begin{array}{c}0.0 \\
(0.33)\end{array}$ & $\begin{array}{l}-0.16^{*} \\
(-1.76)\end{array}$ & $\begin{array}{l}0.01 \\
(0.27)\end{array}$ & $\begin{array}{c}0.3 \\
(1.43)\end{array}$ & $\begin{array}{l}-0.06 \\
(-0.5)\end{array}$ & $\begin{array}{c}0.0 \\
(0.53)\end{array}$ & $\begin{array}{l}-0.02^{* *} \\
(-2.37)\end{array}$ \\
\hline
\end{tabular}


Table VI continued

\begin{tabular}{|c|c|c|c|c|c|c|c|c|c|c|c|c|}
\hline & \multirow{2}{*}{ 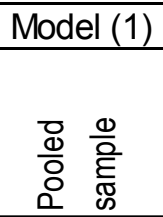 } & \multicolumn{11}{|c|}{ Model (2) } \\
\hline & & 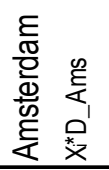 & 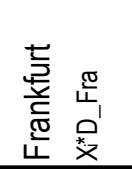 & 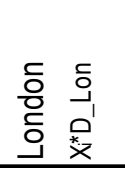 & 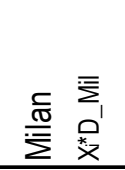 & 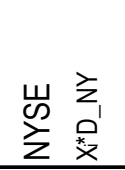 & 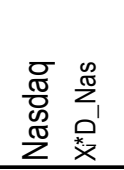 & 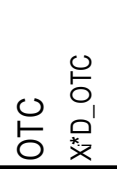 & 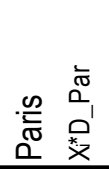 & 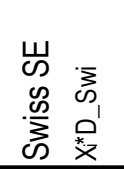 & 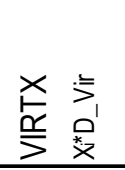 & 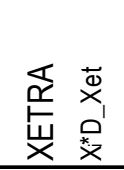 \\
\hline \multirow[t]{2}{*}{ Stock risk } & $5.30^{* *}$ & -5.33 & $16.56^{* * *}$ & -1.63 & 17.93 & $14.92^{* *}$ & $9.89^{* *}$ & 2.66 & -4.13 & $42.76^{* * \star}$ & -7.62 & $14.97^{* * *}$ \\
\hline & (2.53) & $(-0.61)$ & (7.67) & $(-0.43)$ & (1.49) & (2.46) & (2.10) & $(0.61)$ & $(-0.65)$ & (2.72) & $(-0.56)$ & $(3.39)$ \\
\hline \multirow[t]{2}{*}{ Foreign sales } & $0.41^{*}$ & 0.0 & 0.0 & 0.0 & -0.02 & $0.02^{* * *}$ & $0.02^{* *}$ & $0.01^{* *}$ & 0.01 & -0.01 & 0.0 & 0.0 \\
\hline & (1.71) & $(0.26)$ & $(-0.21)$ & $(0.05)$ & $(-1.37)$ & (3.91) & (2.33) & (2.17) & $(0.82)$ & $(-1.06)$ & $(0.33)$ & $(0.86)$ \\
\hline \multirow[t]{2}{*}{ Foreign investors } & $1.12^{* *}$ & -0.02 & 0.0 & 0.01 & 0.0 & $0.03^{* * *}$ & 0.01 & 0.01 & 0.01 & -0.02 & 0.0 & 0.0 \\
\hline & (2.35) & $(-0.80)$ & $(0.52)$ & (1.01) & $(0.03)$ & $(3.01)$ & $(0.18)$ & $(1.09)$ & $(1.23)$ & $(-1.58)$ & $(0.39)$ & $(-0.23)$ \\
\hline \multirow[t]{2}{*}{ Ownership concentration } & -0.30 & 2.58 & -0.26 & 0.98 & $5.60^{*}$ & $-1.25^{* *}$ & -2.38 & -0.94 & -0.83 & 1.5 & -0.45 & -0.16 \\
\hline & $(-1.07)$ & (1.57) & $(-0.80)$ & (1.59) & $(1.81)$ & $(-2.13)$ & $(-1.43)$ & $(-1.56)$ & $(-1.03)$ & (1.55) & $(-0.76)$ & $(-0.28)$ \\
\hline \multirow{2}{*}{$\begin{array}{l}\text { International accounting } \\
\text { standards }\end{array}$} & 0.04 & 0.21 & 0.15 & 0.28 & $2.85^{* * *}$ & $0.42^{* * *}$ & $1.26^{* * *}$ & -0.17 & $0.73^{* *}$ & 232.09 & $10.49^{* *}$ & $-0.51^{* *}$ \\
\hline & $(0.35)$ & $(0.40)$ & (1.20) & (1.23) & $(4.06)$ & (2.81) & (2.93) & $(-0.8)$ & (2.08) & (1.15) & (2.53) & $(-2.57)$ \\
\hline \multirow[t]{2}{*}{ Return correlation } & $-1.20^{* * *}$ & 0.51 & $-1.78^{* * *}$ & -1.02 & 2.98 & $-2.57^{* * *}$ & $-3.91^{*}$ & 0.04 & -0.83 & 0.37 & $1.37^{*}$ & -1.22 \\
\hline & $(-3.23)$ & $\begin{array}{c}(0.29) \\
0.0\end{array}$ & $\begin{array}{l}(-3.98) \\
-0.03\end{array}$ & $\begin{array}{l}(-1.16) \\
0.10^{*}\end{array}$ & $\begin{array}{l}(1.62) \\
-0.02\end{array}$ & $\begin{array}{c}(-3.2) \\
0.0\end{array}$ & $\begin{array}{c}(-1.91) \\
0.06\end{array}$ & $\begin{array}{l}(0.05) \\
0.09^{*}\end{array}$ & $\begin{array}{c}(-0.63) \\
0.02\end{array}$ & $\begin{array}{l}(0.23) \\
0.07\end{array}$ & $\begin{array}{l}(1.68) \\
0.04\end{array}$ & $\begin{array}{c}(-1.62) \\
0.01\end{array}$ \\
\hline Foreign information factor & $0.13^{* \star *}$ & $(-0.08)$ & $(-1.31)$ & $(1.90)$ & $(-0.22)$ & $(-0.15)$ & $(1.07)$ & $(1.68)$ & $(0.40)$ & $(1.54)$ & $(0.87)$ & $(0.18)$ \\
\hline US information factor & (2.94) & & & & & & & & & & & \\
\hline Foreign (non-US) & -0.02 & & & & & & & & & & & \\
\hline information factor & $(-0.87)$ & & & & & & & & & & & \\
\hline \multicolumn{13}{|c|}{ Home market charactersitics } \\
\hline Home emerging market & $\begin{array}{c}1.62^{* * *} \\
(2.87)\end{array}$ & & $\begin{array}{c}3.54^{\star * \star} \\
(6.21)\end{array}$ & $\begin{array}{c}6.16^{* * *} \\
(3.00)\end{array}$ & & $\begin{array}{l}-1.12 \\
(-1.54)\end{array}$ & & $\begin{array}{c}-2.55^{\star * *} \\
(-2.78)\end{array}$ & $\begin{array}{l}2.42^{\star *} \\
(2.41)\end{array}$ & & & \\
\hline Common language & $\begin{array}{c}0.59^{* * *} \\
(2.94)\end{array}$ & & $\begin{array}{c}1.81^{* * *} \\
(4.53)\end{array}$ & $\begin{array}{c}8.70^{* * *} \\
(3.01)\end{array}$ & & $\begin{array}{l}1.05 \\
(0.72)\end{array}$ & $\begin{array}{l}0.27 \\
(0.07)\end{array}$ & $\begin{array}{r}0.77 \\
(0.47)\end{array}$ & & $\begin{array}{l}6.78^{*} \\
(1.86)\end{array}$ & $\begin{array}{l}-0.04 \\
(-0.05)\end{array}$ & $\begin{array}{l}1.11 \\
(1.51)\end{array}$ \\
\hline
\end{tabular}


Table VI continued

\begin{tabular}{|c|c|c|c|c|c|c|c|c|c|c|c|c|}
\hline & \multirow{2}{*}{ 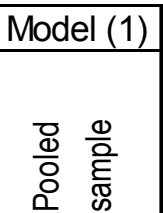 } & \multicolumn{11}{|c|}{ Model (2) } \\
\hline & & 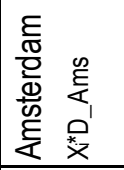 & 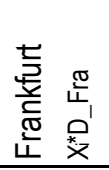 & 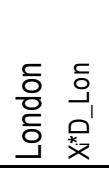 & 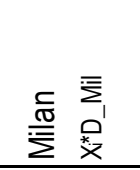 & 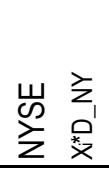 & 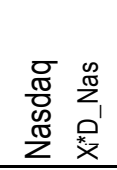 & 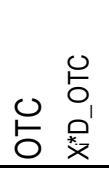 & 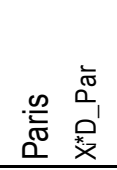 & 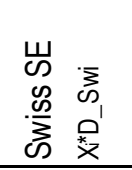 & 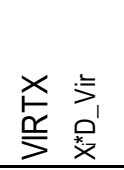 & 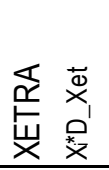 \\
\hline Geographic distance & & $\begin{array}{c}0.2 \\
(0.23)\end{array}$ & $\begin{array}{l}0.09 \\
(0.63)\end{array}$ & $\begin{array}{c}-0.40^{*} \\
(-1.9)\end{array}$ & $\begin{array}{l}0.84 \\
(0.31)\end{array}$ & $\begin{array}{c}0.47 \\
(1.52)\end{array}$ & $\begin{array}{l}0.36 \\
(0.78)\end{array}$ & $\begin{array}{c}0.25 \\
(1.27)\end{array}$ & $\begin{array}{c}-1.08^{* *} \\
(-2.29)\end{array}$ & $\begin{array}{l}5.29 \\
(1.49)\end{array}$ & $\begin{array}{l}-1.01^{*} \\
(-1.71)\end{array}$ & $\begin{array}{l}-0.56^{* \star} \\
(-2.34)\end{array}$ \\
\hline HostUS & $\begin{array}{l}3.79^{* * *} \\
(11.57)\end{array}$ & & & & & & & & & & & \\
\hline $\begin{array}{l}\text { Geographic distance } \\
\text { residual }\end{array}$ & $\begin{array}{l}-0.22 \\
(-1.36)\end{array}$ & & & & & & & & & & & \\
\hline Investor protection Home & $\begin{array}{l}-0.90^{* * *} \\
(-3.12)\end{array}$ & $\begin{array}{c}8.85^{\star * *} \\
(5.14)\end{array}$ & $\begin{array}{l}-0.56 \\
(-0.96)\end{array}$ & $\begin{array}{l}-8.72^{*} \\
(-1.70)\end{array}$ & $\begin{array}{c}12.28^{* *} \\
(2.41)\end{array}$ & $\begin{array}{l}-2.82 \\
(-1.21)\end{array}$ & $\begin{array}{l}-0.57 \\
(-0.11)\end{array}$ & $\begin{array}{l}-2.02 \\
(-0.78)\end{array}$ & $\begin{array}{l}-4.21^{* *} \\
(-2.52)\end{array}$ & $\begin{array}{c}2.99^{* * *} \\
(3.10)\end{array}$ & $\begin{array}{c}-3.22^{* * *} \\
(-5.18)\end{array}$ & $\begin{array}{l}-1.14 \\
(-1.46)\end{array}$ \\
\hline IT laws enforced Home & $\begin{array}{l}-0.77^{* *} \\
(-2.17)\end{array}$ & $\begin{array}{c}0.0 \\
(-0.13)\end{array}$ & $\begin{array}{l}0.0^{* *} \\
(2.02)\end{array}$ & $\begin{array}{c}0.0 \\
(-0.29)\end{array}$ & $\begin{array}{l}0.03^{* *} \\
(2.21)\end{array}$ & $\begin{array}{c}0.0 \\
(-0.19)\end{array}$ & $\begin{array}{c}0.0 \\
(1.00)\end{array}$ & $\begin{array}{c}0.0 \\
(-1.12)\end{array}$ & $\begin{array}{l}0.0^{* *} \\
(2.46)\end{array}$ & $\begin{array}{l}-0.12 \\
(-1.16)\end{array}$ & $\begin{array}{c}0.0 \\
(-1.07)\end{array}$ & $\begin{array}{c}0.0 \\
(0.53)\end{array}$ \\
\hline Trading costs Home & $\begin{array}{c}1.75^{* * *} \\
(3.11)\end{array}$ & $\begin{array}{l}12.2^{*} \\
(2.46)\end{array}$ & $\begin{array}{l}-0.79 \\
(-1.3)\end{array}$ & $\begin{array}{l}5.3^{* * *} \\
(2.66)\end{array}$ & $\begin{array}{c}-42.8^{* * *} \\
(-3.46)\end{array}$ & $\begin{array}{l}-0.53 \\
(-0.50)\end{array}$ & $\begin{array}{l}0.98 \\
(0.32)\end{array}$ & $\begin{array}{c}-0.44 \\
(-0.46)\end{array}$ & $\begin{array}{l}2.69 \\
(1.09)\end{array}$ & $\begin{array}{c}-42.79^{* *} \\
(-2.00)\end{array}$ & $\begin{array}{l}0.84 \\
(0.35)\end{array}$ & $\begin{array}{l}0.33 \\
(0.23)\end{array}$ \\
\hline Accounting opacity Home & -0.42 & -4.07 & -1.06 & $4.15^{* *}$ & $-15.11^{* * *}$ & $-1.47^{*}$ & 10.81 & -0.53 & $-3.35^{* *}$ & 0.0 & $-7.22^{*}$ & -2.80 \\
\hline Intercept & $\begin{array}{c}(-0.58) \\
-6.29^{\star * \star} \\
(-7.21)\end{array}$ & $\begin{array}{c}(-1.03) \\
-8.01^{* * \star} \\
(-20.49)\end{array}$ & $(-1.18)$ & $(2.08)$ & $(-3.08)$ & $(-1.71)$ & (1.64) & $(-0.33)$ & $(-2.39)$ & $(0.0)$ & $(-1.85)$ & $(-1.58)$ \\
\hline Adj. $R$-sq & 0.504 & & 0.674 & & & & & & & & & \\
\hline Nobservations & 51,846 & & 51,846 & & & & & & & & & \\
\hline$N$ foreign accounts & 1,476 & & 1,477 & & & & & & & & & \\
\hline
\end{tabular}


Table VII. Stock-level determinants of the foreign trading volume share

The table reports estimates from the OLS regressions of the dependant variable, the logistic transformation of the foreign trading volume share. The sample includes 599 European cross-listed stocks traded from Jan 2003 to Dec 2007. The stock-level foreign trading share is the ratio of the number of shares traded on the exchange to the total number of the shares traded in the same month on all exchanges in the sample calculated monthly. Model (1) specification is as follows:

$\log \operatorname{trFTVS} S_{i, n}=\alpha_{0}+\Sigma \gamma_{j} X_{j}+\Sigma \theta_{k} Z_{k, n}+\varepsilon_{i, n}$, and Model (2) specification is as follows:

$\log \operatorname{trFTVS}_{i, n}=\alpha_{0}+\sum \gamma_{j, \text { Listed }}\left(D_{\text {Listed }} X_{j}\right)+\sum \theta_{k, \text { Listed }}\left(D_{\text {Listed }} Z_{k, n}\right)+\sum \gamma_{j, \text { Traded }}\left(D_{\text {Traded }} X_{j}\right)+\sum \theta_{k, \text { Traded }}\left(D_{\text {Traded }} Z_{k, n}\right)+\varepsilon_{i, n}$, where $\log \operatorname{tr} F T V S_{i, n}=\ln \left(F T V S_{i, n} /\left(1-F T V S_{i, n}\right)\right), F T V S_{i, n}$ is the stock $i$ 's foreign equity trading volume share on the exchange $n$ in month $t ; X_{j}$ is vector of stock-level factors; $Z_{k, n}$ is characteristic $k$ of the host market $n$ or characteristic $k$ of the host market $n$ relative to characteristic $k$ of the stock's home market; $D_{\text {Listed }}$ is dummy variable that equals one if the stock is listed on a stock exchange $n$ in month $t$ and equals zero otherwise, $D_{\text {Traded }}$ is dummy variable that equals one if the stock is traded without meeting listing requirements on a stock exchange $n$ in month $t$ and equals zero otherwise. Host US indicator is a dummy variable that equals one if the US is the host market and zero otherwise. Geographic distance residual variable is the residual from the OLS regression of the geographic distance variable on the US host market dummy variable. Other explanatory variables are defined in Appendix A. Output additionally includes the economic significance (Econ. sign.) of the variables calculated as the product of the coefficient estimate and the variable's standard deviation divided by the standard deviation of the dependent variable. Reported t-statistics is heteroskedasticity consistent (White, 1980) and adjusted for clustering at the foreign account level. ' $* * *$ ' indicates significance at $1 \%$, ' $* *$ ' indicates significance at $5 \%$ and ' $*$ ' indicates significance at $10 \%$.

\begin{tabular}{l|ccc|cccc}
\hline & \multicolumn{3}{|c|}{ Model (1) } & \multicolumn{3}{c}{ Model (2) } \\
\cline { 2 - 8 } & \multicolumn{3}{|c}{ Pooled sample } & Var ${ }^{*}$ _Listed & Var ${ }^{*}$ _T raded \\
\cline { 2 - 8 } & estimate & t-stats & Econ. sign. & estimate & t-stats & estimate & t-stats \\
\hline Listing characteristics & & & & & & & \\
Traded indicator & $-1.89^{* * *}$ & -10.88 & -0.24 & & & & \\
First listing indicator & $1.86^{* * *}$ & 4.31 & 0.09 & $1.08^{*}$ & 1.92 & & \\
Time listed/ traded & $0.18^{* * *}$ & 10.48 & 0.19 & $0.12^{* * *}$ & 4.24 & $0.22^{* * *}$ & 9.99 \\
Same currency indicator & $1.31^{* * *}$ & 7.98 & 0.18 & $0.89^{* *}$ & 2.48 & $1.55^{* * *}$ & 8.42 \\
DR indicator & $-0.49^{* *}$ & -2.05 & -0.06 & $-1.80^{*}$ & -1.79 & $-0.49^{* *}$ & -2.08 \\
$\quad$ Company characteristics & & & & & & & \\
Company size & $-0.28^{* * *}$ & -5.77 & -0.15 & $-0.20^{* * *}$ & -2.97 & $-0.35^{* * *}$ & -7.04 \\
Stock risk & $6.29^{* * *}$ & 3.55 & 0.05 & $15.88^{* * *}$ & 3.79 & 1.72 & 0.80 \\
Foreign investors & $0.90^{* *}$ & 2.31 & 0.03 & $2.52^{* * *}$ & 3.04 & 0.31 & 0.69 \\
Return correlation & $-1.54^{* * *}$ & -4.04 & -0.08 & $-1.87^{* *}$ & -2.57 & $-1.27^{* * *}$ & -2.97 \\
US information factor & $0.10^{* *}$ & 2.42 & 0.04 & 0.06 & 1.19 & 0.08 & 1.19 \\
Foreign (non-US) information factor & -0.03 & -1.32 & -0.02 & -0.004 & -0.1 & -0.03 & -1.08 \\
$\quad$ Market characteristics & & & & & & & \\
Common language & $0.71^{* * *}$ & 3.49 & 0.08 & 0.42 & 0.97 & $0.58^{* * *}$ & 2.66 \\
Host US indicator & $4.43^{* * *}$ & 10.96 & 0.55 & $6.87^{* * *}$ & 5.79 & $4.04^{* * *}$ & 8.59 \\
Geographic distance residual & $-0.37^{* *}$ & -2.35 & -0.05 & $-0.57^{*}$ & -1.17 & -0.27 & -1.47 \\
Market size difference & -0.06 & -0.53 & -0.03 & -0.20 & -0.90 & -0.14 & -1.07 \\
Market liquidity difference & $-0.32^{* * *}$ & -5.69 & -0.23 & $-0.28^{* * *}$ & -2.72 & $-0.22^{* * *}$ & -3.51
\end{tabular}


Table VII continued

\begin{tabular}{|c|c|c|c|c|c|c|c|}
\hline & \multirow{2}{*}{\multicolumn{3}{|c|}{$\frac{\text { Model (1) }}{\text { Pooled sample }}$}} & \multicolumn{4}{|c|}{ Model (2) } \\
\hline & & & & \multicolumn{2}{|c|}{ Var*D_Listed } & \multicolumn{2}{|c|}{$\operatorname{Var}^{*} D_{\text {T Traded }}$} \\
\hline & estimate & t-stats & Econ. sign & estimate & t-stats & estimate & t-stats \\
\hline Trading costs difference & $-1.33^{* \star \star}$ & -3.17 & -0.08 & $-1.68^{* \star}$ & -2.00 & 0.26 & 0.51 \\
\hline Investor protection difference & $1.47^{\star * *}$ & 4.73 & 0.15 & 1.00 & 1.49 & $1.36^{* * *}$ & 3.96 \\
\hline IT laws enforced difference & $1.12^{* \star *}$ & 3.27 & 0.09 & $3.18^{* *}$ & 3.39 & 0.39 & 1.10 \\
\hline Accounting opacity difference & $4.09^{\star \star *}$ & 5.07 & 0.15 & 2.58 & 1.48 & $4.33^{\star * *}$ & 4.93 \\
\hline Intercept & $-6.15^{\star \star *}$ & -11.23 & & $-10.16^{* * *}$ & -14.87 & & \\
\hline Adj. $R$-sq & 0.526 & & & 0.512 & & & \\
\hline Nobservations & 56,682 & & & 56,682 & & & \\
\hline$N$ foreign accounts & 1,578 & & & 1,578 & & & \\
\hline
\end{tabular}




\section{Appendix A}

Variable definitions and sources

The table presents the list of explanatory variables, indicates whether the variable is used in the exchangelevel and/or the stock level analysis, and provides a definition and data sources for each of the variables.

\begin{tabular}{|c|c|c|c|c|}
\hline Explanatory variable & $\begin{array}{l}\text { Used in } \\
\text { exchange } \\
\text { level } \\
\text { analysis }\end{array}$ & $\begin{array}{l}\text { Used in } \\
\text { stock } \\
\text { level } \\
\text { analysis }\end{array}$ & Definition & Data source \\
\hline \multicolumn{5}{|l|}{ Pull factors } \\
\hline Trading platform indicator & $\mathrm{V}$ & & $\begin{array}{l}\text { dummy varible }=1 \text { if trading takes place on VIRTX, } \\
\text { XETRA trading platforms or on the US OTC market; } \\
=0 \text { otherwise }\end{array}$ & dataset \\
\hline $\begin{array}{l}\text { Demutualization indicator (host } \\
\text { market) }\end{array}$ & V & & $\begin{array}{l}\text { dummy variable }=1 \text { if trading takes place on } \\
\text { demutualized exchang; }=0\end{array}$ & \multirow{2}{*}{$\begin{array}{l}\text { Aggarwal } \\
(2002), \text { stock } \\
\text { Jain (2005) }\end{array}$} \\
\hline $\begin{array}{l}\text { Electronic market indicator (host } \\
\text { market) }\end{array}$ & V & & $\begin{array}{l}\text { dummy varible }=1 \text { after the introduction of an } \\
\text { electronic market on a particular exchange }\end{array}$ & \\
\hline Common language & & V & $\begin{array}{l}\text { dummy variable }=1 \text { if the host and the home } \\
\text { countries share a common official language; }=0 \\
\text { otherwise }\end{array}$ & $\begin{array}{l}\text { Sarkissian } \\
\text { and Shill } \\
(2004)\end{array}$ \\
\hline Geographic distance & & V & $\begin{array}{l}\text { the natural logarithm of the geographic distance in } \\
\text { kilometres between capitals of the host and home } \\
\text { countries }\end{array}$ & $\begin{array}{c}\text { Sarkissian } \\
\text { and Shill } \\
(2004) \\
\end{array}$ \\
\hline Market size (host market) & V & & $\begin{array}{l}\text { the natural logarithm of total market capitalization of } \\
\text { DS Total Market index, converted from local } \\
\text { currency to GBP }\end{array}$ & \multirow[t]{2}{*}{ DataStream } \\
\hline $\begin{array}{l}\text { Market size (host market relative } \\
\text { to home market) }\end{array}$ & & V & $\begin{array}{l}\text { the log-difference between the host total market } \\
\text { capitalization and the home total market capitalization }\end{array}$ & \\
\hline $\begin{array}{l}\text { Aggregate market liquidity (host } \\
\text { market) }\end{array}$ & V & & $\begin{array}{l}\text { market turnover ratio calculated as the ratio of the } \\
\text { total value of the DS Total Market index constituent } \\
\text { shares traded to the DS Total Market index } \\
\text { capitalization }\end{array}$ & \multirow[t]{2}{*}{ DataStream } \\
\hline $\begin{array}{l}\text { Aggregate market liquidity (host } \\
\text { market relative to home market) }\end{array}$ & & V & $\begin{array}{l}\text { the log-difference between the market turnover ratio } \\
\text { of the host and of the home markets }\end{array}$ & \\
\hline Trading costs (host market) & V & & $\begin{array}{l}\text { total trading costs are the sum of price impact costs, } \\
\text { implicit costs and explicit costs }\end{array}$ & \multirow{2}{*}{$\begin{array}{l}\text { Chiyachantan } \\
\text { a et al (2004), } \\
\text { Table V }\end{array}$} \\
\hline $\begin{array}{l}\text { Trading costs (host market } \\
\text { relative to home market) }\end{array}$ & & V & $\begin{array}{l}\text { the difference in total trading costs of the host market } \\
\text { and of the home markets }\end{array}$ & \\
\hline Investor protection (host market) & V & & anti-self-dealing index & \multirow{2}{*}{$\begin{array}{c}\text { Djiankov etal } \\
(2008)\end{array}$} \\
\hline $\begin{array}{l}\text { Investor protection (host market } \\
\text { relative to home market) }\end{array}$ & & V & $\begin{array}{l}\text { the difference in anti-self-dealing index of the host } \\
\text { market and of the home markets }\end{array}$ & \\
\hline $\begin{array}{l}\text { Insider trading laws enforced } \\
\text { (host market) }\end{array}$ & V & & $\begin{array}{l}\text { dummy variable }=0 \text { before enforcement of insider } \\
\text { trading laws and }=1 \text { in the year of enforcement of } \\
\text { insider trading regulation and thereafter }\end{array}$ & \multirow[t]{2}{*}{$\begin{array}{l}\text { Bhattacharya } \\
\text { and Daouk } \\
\text { (2002) }\end{array}$} \\
\hline $\begin{array}{l}\text { Insider trading laws enforced } \\
\text { (host market relative to home } \\
\text { market) } \\
\end{array}$ & & V & $\begin{array}{l}\text { non-negative difference between the insider trading } \\
\text { laws enforcement variable of the host and of home } \\
\text { countries (1) }\end{array}$ & \\
\hline Accounting opacity (host market) & V & & accounting opacity index & \multirow{2}{*}{$\begin{array}{c}\text { Kurtzman et al } \\
(2004)\end{array}$} \\
\hline $\begin{array}{l}\text { Accounting opacity (host market } \\
\text { relative to home market) }\end{array}$ & & V & $\begin{array}{l}\text { the difference in the accounting opacity index of the } \\
\text { host country and index of the home country }\end{array}$ & \\
\hline \multicolumn{5}{|l|}{ Stock-level factors } \\
\hline \multicolumn{5}{|l|}{ Listing characteristics } \\
\hline Traded (vs. exchange-listed) & & V & $\begin{array}{l}\text { traded indicator }=1 \text { if the stock is traded on the US } \\
\text { OTC, London OTC, open market of Deutsche } \\
\text { Bourse, or VIRTX; =0 otherwise }\end{array}$ & dataset \\
\hline
\end{tabular}


Appendix A continued

\begin{tabular}{|c|c|c|c|c|}
\hline Explanatory variable & $\begin{array}{c}\text { Used in } \\
\text { exchange } \\
\text { level } \\
\text { analysis }\end{array}$ & $\begin{array}{c}\text { Used in } \\
\text { stock } \\
\text { level } \\
\text { analysis }\end{array}$ & Definition & Data source \\
\hline First foreign listing & & $\mathrm{V}$ & $\begin{array}{l}\text { dummy variable = } 1 \text { if the foreign account is the fist } \\
\text { and the only foreign listing of the stock; }=0 \text { otherwise }\end{array}$ & dataset \\
\hline Time listed/ traded & & V & $\begin{array}{l}\text { the number of years a stock has been listed or } \\
\text { traded on a particular exchange }\end{array}$ & dataset \\
\hline Price level & & V & $\begin{array}{l}\text { the natural logarithm of the stock price on a particular } \\
\text { exchange denominated in GBP }\end{array}$ & Datastream \\
\hline The same currency of listing & & V & $\begin{array}{l}\text { dummy variable }=1 \text { if foreign trading takes place in } \\
\text { the same currency as home trading; }=0 \text { otherwise }\end{array}$ & Datastream \\
\hline$\overline{D R}$ (vs. ordinary listing) & & $\mathrm{V}$ & $\begin{array}{l}\text { dummy variable }=1 \text { if the listing is in the form of a } \\
\text { depository receipt; }=0 \text { otherwise }\end{array}$ & dataset \\
\hline \multicolumn{5}{|l|}{ Company characteristics } \\
\hline Company size & & V & $\begin{array}{l}\text { market value of the company's share at the end of } \\
\text { the preceding year }\end{array}$ & Datastream \\
\hline Company growth opportunities & & $\mathrm{V}$ & $\begin{array}{l}\text { price-to-book value ratio at the end of the preceding } \\
\text { year. If not available from Datastream, it is calculated } \\
\text { as the ratio of the stock price to the company's book } \\
\text { value }\end{array}$ & Datastream \\
\hline Company foreign sales & & V & $\begin{array}{l}\text { the fraction of foreign sales in company's total net } \\
\text { sales in the preceding year }\end{array}$ & Datastream \\
\hline $\begin{array}{l}\text { Foreign investors - company's } \\
\text { foreign institutional ownership }\end{array}$ & & V & $\begin{array}{l}\text { the percentage of total shares held by an institution } \\
\text { domiciled in a country other than that of the company } \\
\text { at the end of the preceding year }\end{array}$ & Datastream \\
\hline Ownership concentration & & $\mathrm{V}$ & $\begin{array}{l}\text { calculated as one minus the percentage of total } \\
\text { shares available to ordinary investors at the end of } \\
\text { the preceding year }\end{array}$ & Datastream \\
\hline Stock return variance & & V & $\begin{array}{l}\text { standard deviation of stock weekly returns over the } \\
\text { preceding } 12 \text { months, calculated for each month }\end{array}$ & Datastream \\
\hline $\begin{array}{l}\text { International accounting } \\
\text { standards used }\end{array}$ & & V & $\begin{array}{l}\text { dummy variable }=1 \text { if the company used } \\
\text { international accounting standards or US GAAP in } \\
\text { the end of the preceding year; }=0 \text { otherwise }\end{array}$ & Datastream \\
\hline $\begin{array}{l}\text { Stock retrun correrlation with } \\
\text { foreign market }\end{array}$ & & V & $\begin{array}{l}\text { correlation coefficient of weekly stock returns and } \\
\text { foreign index returns over preceding } 36 \text { (at least } \\
\text { 24) months, computed for each month }\end{array}$ & Datastream \\
\hline Foreign information factor & & V & $\begin{array}{l}\text { Foreign information factor calculated using } \\
\text { methodology of Baruch et al (2007) }\end{array}$ & Datastream \\
\hline \multicolumn{5}{|l|}{ Home market characteristics } \\
\hline $\begin{array}{l}\text { Level of development (home } \\
\text { market) }\end{array}$ & & V & $\begin{array}{l}\text { emerging market indicator }=1 \text { if the stock is from } \\
\text { emerging market; }=0 \text { otherwise }\end{array}$ & $\mathrm{MSCl}$ list \\
\hline $\begin{array}{l}\text { Investor protection (home } \\
\text { market) }\end{array}$ & & V & anti-self-dealing index & $\begin{array}{c}\text { Djiankov et al } \\
(2008)\end{array}$ \\
\hline $\begin{array}{l}\text { Insider trading laws enforced } \\
\text { (home market) }\end{array}$ & & V & $\begin{array}{l}\text { dummy variable }=0 \text { before enforcement of insider } \\
\text { trading laws and }=1 \text { in the year of enforcement of } \\
\text { insider trading regulation and thereafter }\end{array}$ & $\begin{array}{l}\text { Bhattacharya } \\
\text { and Daouk } \\
(2002)\end{array}$ \\
\hline $\begin{array}{l}\text { Accounting opacity (home } \\
\text { market) }\end{array}$ & & V & accounting opacity index & $\begin{array}{c}\text { Kurtzman etal } \\
(2004)\end{array}$ \\
\hline Trading costs (home market) & & V & $\begin{array}{l}\text { total trading costs are the sum of price impact costs, } \\
\text { implicit costs and explicit costs }\end{array}$ & $\begin{array}{l}\text { Chiyachantana } \\
\text { et al (2004), } \\
\text { Table V }\end{array}$ \\
\hline
\end{tabular}

